\title{
Chimeric Antigen Receptor T-Cells for the Treatment of B-Cell Acute Lymphoblastic Leukemia
}

\author{
Ciprian Tomuleasa ${ }^{1,2 *}$, Shigeo Fuji ${ }^{3}$, Cristian Berce ${ }^{4}$, Anca Onaciu ${ }^{5}$, Sergiu Chira ${ }^{5}$, \\ Bobe Petrushev ${ }^{5}$, Wilhelm-Thomas Micu ${ }^{5}$, Vlad Moisoiu ${ }^{5}$, Ciprian Osan ${ }^{5}$, \\ Catalin Constantinescu ${ }^{6}$, Sergiu Pasca ${ }^{5}$, Ancuta Jurj ${ }^{5}$, Laura Pop ${ }^{5}$, \\ loana Berindan-Neagoe ${ }^{5}$, Delia Dima ${ }^{1}$ and Shigehisa Kitano ${ }^{7}$
}

${ }^{1}$ Department of Hematology, Oncology Institute Prof. Dr. Ion Chiricuta, Cluj Napoca, Romania, ${ }^{2}$ Research Center for Functional Genomics and Translational Medicine, Department of Hematology, Iuliu Hatieganu University of Medicine and Pharmacy, Cluj Napoca, Romania, ${ }^{3}$ Department of Stem Cell Transplantation, Osaka International Cancer Institute, Osaka, Japan, ${ }^{4}$ Animal Facility, Iuliu Hatieganu University of Medicine and Pharmacy, Cluj Napoca, Romania, ${ }^{5}$ Research Center for Functional Genomics and Translational Medicine, Iuliu Hatieganu University of Medicine and Pharmacy, Cluj Napoca, Romania, ${ }^{6}$ Department of Hematology, I lilu Hatieganu University of Medicine and Pharmacy, Cluj Napoca, Romania, 7Division of Cancer Immunotherapy, Department of Experimental Therapeutics, National Cancer Center Hospital, Tokyo, Japan

\section{OPEN ACCESS}

Edited by:

Yun-Cai Liu,

Tsinghua University, China

Reviewed by:

Taisuke Kondo,

Keio University, Japan

Shunsuke Chikuma,

Keio University, Japan

*Correspondence:

Ciprian Tomuleasa

ciprian.tomuleasa@umfcluj.ro

Specialty section:

This article was submitted to

T Cell Biology,

a section of the journal

Frontiers in Immunology

Received: 07 November 2017

Accepted: 29 January 2018

Published: 19 February 2018

Citation:

Tomuleasa C, Fuji S, Berce C, Onaciu A, Chira S, Petrushev B,

Micu W-T, Moisoiu V, Osan C, Constantinescu C, Pasca S, Jurj A,

Pop L, Berindan-Neagoe I, Dima D and Kitano S (2018) Chimeric

Antigen Receptor T-Cells for the

Treatment of B-Cell Acute

Lymphoblastic Leukemia.

Front. Immunol. 9:239.

doi: 10.3389/fimmu.2018.00239
Chimeric antigen receptor (CAR) T-cell technology has seen a rapid development over the last decade mostly due to the potential that these cells may have in treating malignant diseases. It is a generally accepted principle that very few therapeutic compounds deliver a clinical response without treatment-related toxicity, and studies have shown that CAR T-cells are not an exception to this rule. While large multinational drug companies are currently investigating the potential role of CAR T-cells in hematological oncology, the potential of such cellular therapies are being recognized worldwide as they are expected to expand in the patient to support the establishment of the immune memory, provide a continuous surveillance to prevent and/or treat a relapse, and keep the targeted malignant cell subpopulation in check. In this article, we present the possible advantages of using CAR T-cells in treating acute lymphoblastic leukemia, presenting the technology and the current knowledge in their preclinical and early clinical trial use. Thus, this article first presents the main present-day knowledge on the standard of care for acute lymphoblastic leukemia. Afterward, current knowledge is presented about the use of CAR T-cells in cancer immunotherapy, describing their design, the molecular constructs, and the preclinical data on murine models to properly explain the background for their clinical use. Last, but certainly not least, this article presents the use of CAR T-cells for the immunotherapy of B-cell acute lymphoblastic leukemia, describing both their potential clinical advantages and the possible side effects.

Keywords: acute lymphoblastic leukemia, immunotherapy, chimeric antigen receptor T-cell therapy (CAR-T), gene transferred T-cell therapy, adoptive cell transfer

\section{CURRENT MANAGEMENT OF ACUTE LYMPHOBLASTIC LEUKEMIA (ALL)}

Acute leukemias are classified into acute myeloid leukemia (AML) and ALL, depending on the result of immunophenotype characterization. The latest World Health Organization classification replaced the classic cytological classification of ALLs into B-cell ALL and T-cell ALL. B-cell ALL and acute lymphoblastic lymphomas are malignancies with B-cell lymphoblasts (1-3). In B-cell ALLs, 
the bone marrow aspirate will detect at least $20 \%$ bone marrow lymphoblasts, with this type of malignancies representing around $85 \%$ of all pediatric ALLs (4-6). The accurate diagnosis is made after flow cytometry immunophenotyping, with positive cells for CD10, CD19, CD20, CD22, CD24, and CD79a. For these patients, karyotype analysis shows frequent alterations such as hyperploidy or $\mathrm{t}(12 ; 21)(\mathrm{p} 13 ; \mathrm{q} 22)$, i.e., associated with a favorable prognosis. Cytogenetic alterations with poor prognosis are $\mathrm{t}(19 ; 22)(\mathrm{q} 34 ; \mathrm{q} 11.2), \mathrm{t}(1 ; 19)(\mathrm{q} 23 ; \mathrm{p} 13.3)$ or $\mathrm{t}(4 ; 11)(\mathrm{q} 21 ; \mathrm{q} 23)$ translocations $(7-10)$.

For these malignancies, the prognosis in pediatric patients is excellent with $90-95 \%$ of cases achieving complete remission after chemotherapy. First-line chemotherapy for patients with ALL younger than 65 years is the intensive chemotherapy like Hoelzer protocol or hyper-CVAD (11). In patients with $\mathrm{Ph}^{+} \mathrm{ALL}$, chemotherapy in combination with tyrosine kinase inhibitors (TKIs) is preferred (12). $\mathrm{Ph}^{+} \mathrm{ALL}$ patients were considered to be at high risk for disease progression or relapse before TKIs were introduced. However, the clinical outcome of patients with $\mathrm{Ph}^{+} \mathrm{ALL}$ has been significantly improved with the addition of TKIs (13). For patients with relapsed ALLs younger than 65 years, the salvage chemotherapy regimen is not well established $(14,15) . \mathrm{Ph}^{+}$ALLs can be treated with a protocol in combination of chemotherapy with TKI (16). For older patients, with comorbidities, therapy consists of $600-800 \mathrm{mg} /$ day of imatinib plus $1 \mathrm{~g} / \mathrm{kg}$ prednisone for 30 days and continues with the administration of $600-800 \mathrm{mg}$ imatinib on the long term. For older patients, induction chemotherapy includes the administration of vincristine plus doxorubicin, dexamethasone, or prednisone and intrathecal administration of $15 \mathrm{mg}$ methotrexate at day 1 (17). As maintenance therapy, patients receive a less-intensive continuation regimen.

Allogeneic stem cell transplantation (SCT) is indicated in B-cell ALL for the patients with a second complete remission, after the failure of the first-line chemotherapy. Patients may undergo up-front allogeneic SCT in complete remission if they have unfavorable prognostic factors $(18,19)$, including positive minimal residual disease (MRD). The term MRD represents the low-level disease, which persists and is characterized by the presence of a few malignant phenotype bearing cells not detectable by morphologic criteria (20). MRD has an incredibly important prognostic value in hematological malignancies, with laboratory protocols evolving into routing follow-up of patients who undergo chemotherapy. Such tools include multiparametric flow cytometry and quantitative PCR of Ig $(19,21)$. Flow cytometry is used to detect the aberrant immunophenotypes of malignant cells, but this method is pushed at limits not present in all laboratories. The role of detecting MRD is to help in taking therapeutic decisions regarding continuing or not a treatment taking into consideration the number or malignant cells that remained in that patient and that can cause relapse $(22,23)$.

In patients with relapsed/refractory $\mathrm{Ph}$-negative $\mathrm{B}$-ALL, blinatumomab can be an option. Blinatumumab is a byspecific antibody that targets both CD3 and CD19, and it has a reported complete remission rate of $67 \%$, but it is also associated with adverse effects such as cytokine release syndrome (CRS), high fever, nausea, headaches, and hepatic and neurologic side effects
(24-27). For Ph-negative ALL, in August 2017, the Food and Drug Administration (FDA) approved the use of inotuzumab ozogamicin $(28,29)$, a monoclonal antibody anti-CD22, but also chimeric antigen receptor (CAR) T-cells (30).

\section{CAR T-CELLS IN CANCER IMMUNOTHERAPY}

The principle of this immunotherapy involves genetic engineering on patient T-cells to express a surface receptor for direct targeting the tumor cells. Bu using a recombinant technology, a T-cell receptor (TCR) construct was developed, formed by tumor associate antigen-specific single-chain variable fragment (scFv) antibody that is fused with a transmembrane domain (TMD) and then with a intracellular T-cell signaling domain. All these processes leaded to a CAR capable of specific tumor cell binding and activating T-cells to achieve cytotoxic potential (Figure 1).

Chimeric antigen receptor T-cell therapy emerges with various advantages, both from a basic science point of view as well as for clinicians. First, CAR T-cells act independent of the HLA phenotypes, becoming useful for different patients, no matter if their cells express it or not because some tumors tend to downregulate it. The therapy acts in both $\mathrm{CD}^{+}$and $\mathrm{CD}^{+}$cells and allows for additional $\mathrm{T}$ helper and $\mathrm{T}$ cytotoxic cell action.

Chimeric antigen receptor $\mathrm{T}$-cell technology has seen a rapid development over the last decade following the potential that these cells have in treating malignant diseases (31-33). The use of animal models in the preclinical assessment of CAR T-cells makes the molecular and genetic mechanisms of these cells interacting with a certain pathological process accessible to research and experiments, which would otherwise be obviously impossible in humans due to ethical reasons. Thus, the ethical justification of developing such animal models would be to have an experimental approach in extending the knowledge of CAR T-cells. By using these animal models, we have to assess not only the potential that these modified cells would have as a therapeutic approach in various malignancies but also the potential toxic effects that these cells may have on healthy organs.

It is a generally accepted principle that very few therapeutic compounds deliver a clinical response without toxicity, and studies have shown that CAR T-cells are not an exception to this rule (34). Still, a harm-benefit analysis that would be in favor of a positive clinical outcome would sway the balance in the potential use of these cells in a clinical setting. While classical chemotherapy is related with non-selective cytotoxicity such as mucositis and myelosuppression, CAR T-cell therapy (CAR-T) is related with a specific type of toxicity expressed as immunemediated adverse effects. Some authors have reported the fact that these adverse effects may persist in the long term, extending the duration of possible toxicities beyond that of conventional pharmaceutical molecules $(34,35)$, as transplanted CAR T-cells have been shown to survive up to 6 months in human patients (36), after having been expanded ex vivo for up to 56 days with partially insufficient costimulation (37).

One of the first documented adverse effects of CAR-T in clinical use is the CRS and B-cell aplasia (38-42). CRS is caused mainly by the expansion of the infused T-cells (43), but other cells 


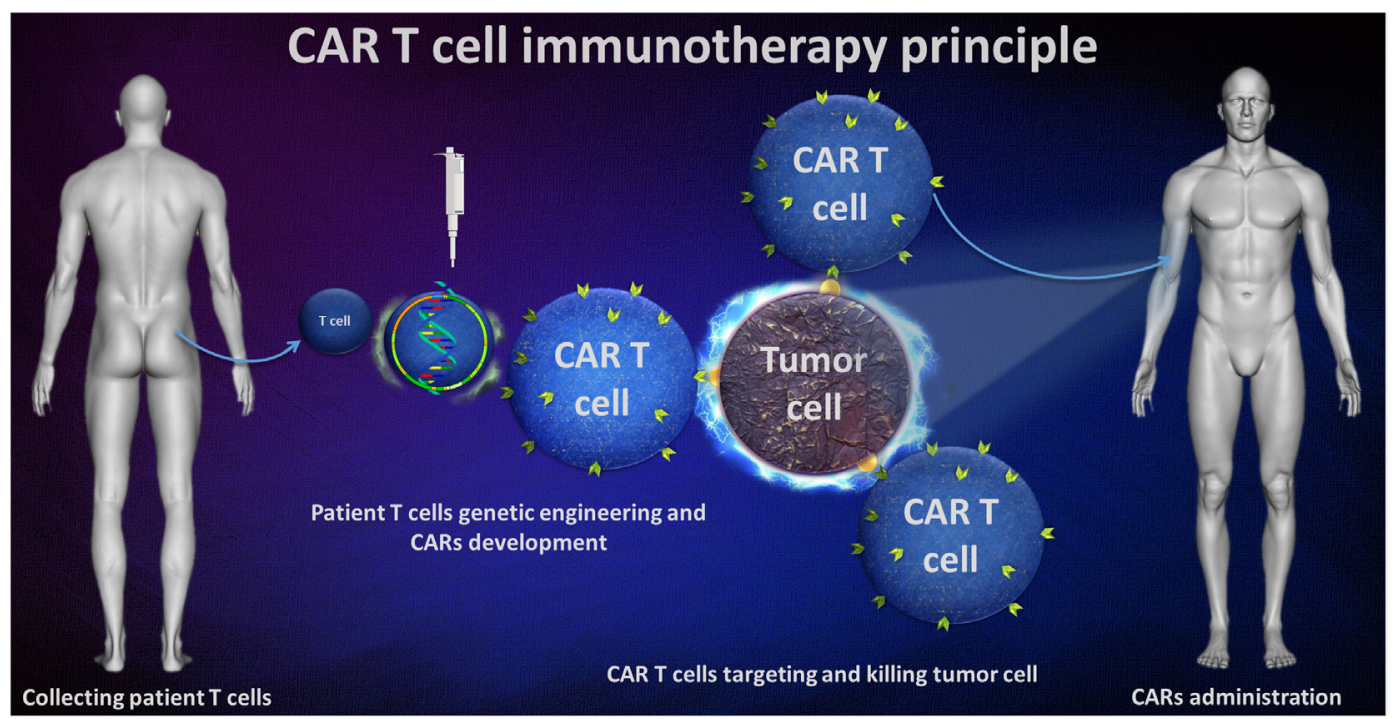

FIGURE 1 | Chimeric antigen receptor (CAR) T-cell immunotherapy principle.

including B, T, and natural killer (NK) cells, and myeloid cells such as dendritic cells, monocytes, and macrophages seems to contribute to the development of CRS. All of these cells become active and release en-masse inflammatory cytokines, thus the paraclinical hallmark of this syndrome being elevated levels of these cytokines. The current concepts in the diagnosis and management of CRS classifies the clinical and laboratory parameter range from mild CRS, expressing constitutional symptoms and grade 2 organ toxicity, to severe CRS, which shows a grade 3 organ toxicity and prompts the need for an aggressive clinical intervention because of the potentially life-threatening toxicity $(41,44)$. CRS usually occurs around 6 days after the cells are transplanted (41, 45-47). Organ damage appears when engineered T-cells cross-react with a normal tissue or cells that has similar antigen expression with the malignant one $(48,49)$. The timing between CAR T-cell infusion and CRS is linked often to the release of inflammatory cytokines such as interleukin (IL)-6, interferongamma, tumor necrosis factor (TNF), IL-2, IL-10, or IL-8. The increased concentration of these molecules is linked to clinical symptoms such as fever or arterial hypotension. Blood tests will show at this point a peak ferritin level, a peak C-reactive protein level, and significant expansion of CAR T-cells, as detected by flow cytometry (50-53).

Cytokine release syndrome may be linked to the activity of CAR T-cells taking into consideration the immunological cascade following the T-cell activation mediated by the CARs in opposition to native TCR activation, with important clinical consequences, as stressed out by Singh et al. (54). Furthermore, Teachey et al. (55) present the cases of patients treated at the University of Pennsylvania who have died with a diagnosis of CRS and provided a detailed cytokine profile, concluding that cytokine dynamics is similar to the dynamics of hemophagocytic lymphohistiocytosis. The systemic inflammation is driven by macrophage activation and by elevation in IL-6. A fast and efficient of CRS resolution by IL- 6 blockade is achieved by the administration of tocilizumab, a drug used primarily for the treatment of juvenile idiopatic arthritis, according to the FDA. It is also approved in Japan for the treatment of Castleman's disease and is dosed for CRS every $2-4$ weeks, being self-limited and without requiring extended treatment.

Hypogammaglobulinemia is often accompanied with a history of recurrent infections, with the site of infection providing clues to the significance and the type of immune deficiency, as well as to the type of microorganism. Infections often affect both the upper and lower respiratory tracts (sinopulmonary infections, sinusitis, bronchitis/bronchiectasis, or pneumonia) or the gastrointestinal tract (parasitic or bacterial gastroenteritis), as well as infections of the joints or skin. Less common symptoms include septicemia or osteomyelitis (56-58). Immunoglobulin replacement therapy should be considered in patients with severe hypogammaglobulinemia as in primary immunodeficiency $(59,60)$.

Taking into consideration all aspects in CAR T-cell design and experimental assessment, in this article, we aim to describe the main aspects in CAR T-cell use in ALL, from their molecular structure, to preclinical models and assessment in clinical trials.

\section{DESIGN OF CAR T-CELLS}

Upon harvesting from patient's peripheral blood and enrichment, primary T-cells need to be genetically modified for CAR T-cell production (61). A gold standard for transduction of primary T-cells is represented by lentiviral vectors (62-67), as a safer alternative to the retroviral vectors, which pose a genotoxic effect on the genome (68). By their integrative capacity into the host genome, expression of CAR transgenic construct can persist independent of cell division. This characteristic makes lentiviral vectors attractive tools for engineering of CAR T-cells. To limit their natural tropism toward $\mathrm{CD} 4^{+}$expressing cells, such as $\mathrm{T}$ helper lymphocytes, the lentiviral capsid has subjected to extensive pseudotyping with other viral glycoproteins. Toward 
this end, vesicular stomatitis virus gp (VSV-G) is the most commonly used glycoprotein for pseudotyping of lentiviral vectors, which offers a broad spectrum of infectivity for different cell types (69-71). However, transduction of quiescent cells, such as B-cells and $\mathrm{T}$ lymphocytes, are not permissive to transduction with VSV-G pseudotyped lentiviral vectors; therefore, new glycoproteins have been investigated toward this end. Measles virus (MV) hemagglutinin $(\mathrm{H})$ and fusion $(\mathrm{F})$ glycoproteins have shown promise for pseudotyping of lentiviral vectors, displaying an affinity for quiescent T- and B-cells $(72,73)$. The drawback of $\mathrm{MV}$-pseudotyped lentiviral vectors is the low titer of virus when compared to the more commonly used VSV-G-pseudotyped lentiviral vectors. Using anion-exchange chromatography might offer an advantage over conventional methods for concentration of viral particles from cellular supernatant, reducing the volume of virus needed for transduction of quiescent lymphocytes (72). Recently, mRNA transfer technologies by electroporation and by endocytosis are proposed as new viral toxicity-free methods, which may also allow the expression of CAR in short term, thus resulting in suppressing cross-reactivity (74).

Although CAR-T has shown promise in clinical setups, there are several limitations that arise from a rapid expansion of the CAR T-cells in vivo, which can result in severe cytokine release upon antigen recognition (75). In addition, for anti-CD19 CAR T-cells, the inability to discriminate malignant from normal B-cells can lead to long-term B-cell aplasia (53). Therefore, controlling the function of CAR T-cells would be highly desirable for reducing these potential life-threatening adverse effects. In this regard, researchers have used antibody-based switch molecules that intermediate the immunological synapse between CAR T-cells and malignant cells, leading to a regulated cytotoxic activity $(66,67)$. Engineered T-cells represent modern-day therapeutic options for cellular therapies, with improved safety and versatility when compared to classic cell therapies, such as SCT. Switch molecules are peptide-engrafted antibody-based molecules that could be used to titrate the therapy to minimize organ toxicity that appears as a result of shared antigen expression with normal tissues. A switch activates a CAR T-cell when it is triggered by both rimiducid and the targeted antigen expressed on the surface of leukemia cells. Current generation CAR T-cell constructs consist of a CD3- $\zeta$ domain and one or more costimulatory molecules that are both activated when a cancer antigen binds to the portion of the CAR on the surface of the engineered T-cell. This reliance on antigen for activation of the CAR T-cell results in an unpredictable and inherently uncontrollable therapeutic effect. CAR T-cells that target CD19 have been shown to proliferate in excess of 2.200- to 2.500-fold ex vivo expansion in some patients, ultimately comprising over $50 \%$ of circulating lymphocytes (76). CAR T-cells for solid tumor, on the other hand, often fail to proliferate or persist at all for more than a few days or weeks and have been largely ineffective (77-80). In normal physiology, conventional T-cells recognize single antigens, but a CAR can be modified to recognize multiple surface antigens, as is the case of universal ectodomain CARs, which incorporate either avidin or a FITC-specific scFvs and recognize malignant cells with multiple antigens $(66,81-83)$. This is the case of solid tumor antigens targeted by CARs and include CD171, folate receptor $\alpha$, human growth factor receptor 2 (Her2/neu), carcinoembryonic antigen, or the vascular endothelial growth factor receptor 2 (84). The physician has no effective way to intervene to achieve greater consistency once the cells have been administered. The switch molecule technology is designed to separate the dual costimulatory domain, MC, from the antigen recognition domain and moves it onto a separate molecular switch that rimiducid can control. This separation is designed to control the degree of activation of the CAR T-cells through adjustments to the schedule of rimiducid administration, but still in a tumor-dependent manner. This additional control system allows the engineered $\mathrm{T}$ lymphocyte to be "turned off" after the disease remission and tumor elimination with negative MRD. Thus, theoretically, healthy B-cells may repopulate the bone marrow of the leukemia or lymphoma patient. In addition, this strategy can offer an increased specificity for malignant cells, which can be extended for solid tumors as well, as presented in Table $\mathbf{1}$.

TABLE 1 | Current clinical trials regarding CAR T-cell therapy.

\begin{tabular}{|c|c|c|c|c|c|}
\hline Type of CAR T-cell & $\begin{array}{l}\text { Targeted tumor } \\
\text { antigen }\end{array}$ & Characteristics & Phase & Coordinating institution & Reference \\
\hline $\begin{array}{l}\text { CD3- } \zeta \text { domain and one } \\
\text { or more costimulatory } \\
\text { molecules }\end{array}$ & CD19 & $\begin{array}{l}\text { Proliferate in excess of } 2.200 \text { - to } \\
2.500 \text {-fold ex vivo expansion in some } \\
\text { patients, ultimately comprising over } \\
50 \% \text { of circulating lymphocyte }\end{array}$ & Phase I clinical trial & $\begin{array}{l}\text { MD Anderson Cancer Center, } \\
\text { Houston, USA }\end{array}$ & $(76)$ \\
\hline \multirow[t]{2}{*}{$\begin{array}{l}\text { Control of } \\
\text { CAR T-cell activity }\end{array}$} & $\begin{array}{l}\text { Switchable CAR } \\
\text { T-cell }\end{array}$ & Dimerizing small molecules & Preclinical research & $\begin{array}{l}\text { Cellectis, New York, USA } \\
\text { University of California in San Francisco, USA }\end{array}$ & $\begin{array}{l}(85) \\
(86)\end{array}$ \\
\hline & Suicide gene & $\begin{array}{l}\text { iCasp9 } \\
\text { Antibody-mediated depletion }\end{array}$ & $\begin{array}{l}\text { Phase I clinical trial } \\
\text { Phase I clinical trial }\end{array}$ & $\begin{array}{l}\text { Baylor College of Medicine, Houston, USA } \\
\text { Fred Hutchinson Cancer Center, Seattle, USA }\end{array}$ & $\begin{array}{l}(87) \\
(88)\end{array}$ \\
\hline Masked CAR T-cell & & Enhance selectivity of CAR T-cells & Preclinical research & CytomX Therepeutics, San Francisco, USA & (89) \\
\hline Enhance of activity & scFv & Enhance selectivity of CAR T-cells & Preclinical research & MD Anderson Cancer Center, Houston, USA & $(90)$ \\
\hline \multirow{2}{*}{$\begin{array}{l}\text { Combinatorial antigen } \\
\text { targeting }\end{array}$} & & SynNotch CAR circulation & Preclinical research & University of California in San Francisco & $(91)$ \\
\hline & & iCAR & Preclinical research & $\begin{array}{l}\text { Memorial Sloan Kettering Cancer Center, } \\
\text { New York, USA }\end{array}$ & (92) \\
\hline
\end{tabular}

CAR, chimeric antigen receptor; scFv, single-chain variable fragment. 
Another safety concern is related to insertional mutagenesis potential of integrating vectors. Although an important step was made by switching from oncoretroviral vectors to lentiviral vectors, which are considered as a safer alternative to the former ones due to a relative random insertional pattern. However, the oncogenic potential of lentiviral vectors has been previously reported $(93,94)$, and this might raise safety issues regarding the use of integrating vectors. Toward this end, efforts have been made to reduce the insertional mutagenesis potential of delivery vectors for CAR into T-cells. Generation of integration-deficient lentiviral vectors and inclusion of a scaffold/matrix-associated region (S/MAR) in the vector backbone displayed comparable cytotoxic effect of CAR T-cells engineered with non-integrating vectors to those that have the integration function unaffected (95). Non-integrating vectors due to the presence of S/MAR element in their design are maintained in subsequent cell generation as an episome.

An alternative to lentiviral vectors could be represented by transposons, as they have been described as efficient gene delivery vectors and has been used for gene therapy applications in clinical trials (96-98). DNA transposons have been used as gene delivery vehicles instead of retrotransposons because their genomic insertions have not been associated with any human disease (99). However, delivery of the transgene is mediated by an encoding transposase that must be provided in trans from the same construct or a second construct, and this might add an extra level of complexity to the experimental setup.

Yet, another alternative to both viral and non-viral delivery could be represented by the newly described gene editing tool, named CRISPR/Cas9 $(100,101)$. This technology offers the possibility to target virtually any genomic site in a RNA-guided manner. The editing complex futures the Cas9 nuclease and a guide RNA, composed of a CRISPR RNA (crRNA) and a transacting crRNA. Upon hybridization of the crRNA to the target sequence, Cas 9 generates a double-strand break, which can be repaired by non-homologous end joining, an event that can result in a loss of function of the genomic locus. In the presence of a donor DNA, by a mechanism of homology-directed recombination, an exogenous sequence can be introduced into the targeted locus $(102,103)$. This knock-in capability of CRISPR/ Cas 9 can be exploited to deliver CAR expression cassette in a desired genomic locus that does not interfere with gene function and therefore minimizing the genotoxic effects experienced with integrating viral vectors. Recent improvements in gRNA and Cas9 have reduced the off-target effects to a minimum, increasing the chances of CRISPR/Cas9 to reach clinical applicability. Up to date, CRISPR/Cas9 already proved its applicability in the field of immunotherapy by enhancing CAR T-cells potency by knockout diverse genes to improve target recognition and cytotoxic activity (104). This technology can be used to knockout PD-1 or the endogenous TCR in NY-ESO-1 TCR transduced T-cells $(104,105)$. Therefore, CRISPR/Cas9 will surely make a difference in advancing immunotherapies for malignant disorders, in both hematological and solid cancers. However, further improvements in delivery systems are still to be made, and as stated above, designing more specific and regulated systems are desirable to achieve a controlled activity of CAR T-cells.
Still, interesting and exciting features of CAR T-cells have been described by Kawalekar et al. (106), who have concluded that 4-1BB CAR but not CD28 CAR induce memory formation and enhance mitochondrial function and antitumoral potential. Additional functions of CAR T-cells enhance their efficacy as strong persistence is achieved by FAS signal inhibition (107). Gattinoni et al. even suggest that early memory T-cell subsets are suitable candidate for CAR T-cell-based therapy (108).

\section{CLASSICAL CAR CONSTRUCTS}

The design of CARs can vary, and currently, there are three generations of CARs (Figure 2). The main components of a CAR system are the CD3 zeta intracellular domain of the TCR, the TMD, the hinge, and a scFv. As a result of this composition, the CAR can be defined as a hybrid antigen receptor (109). This basic system describes the first generation of CARs.

The design of the scFv influences the efficiency and the specificity of CAR T-cells in targeting malignant cells. In most cases, it has a murine origin, which determines the anti-CAR immune responses. In spite of their specificity for tumor antigens, in some cases, CAR T-cells target and kill normal cells, resulting in B-cell aplasia, loss of immunity, and finally long-term effects on the patient's health that may eventually lead to death (58, 110-112). To minimize these drawbacks, further more sophisticated designs of CARs must be developed.

In the design of CARs, key elements are the connection components such as the hinge (also called spacer) and TMD. They form a bound between scFvs and the intracellular domain and are responsible for CARs position and attachment in T-cell membrane. Besides this structural role in CARs design, the hinge morphology characteristics, such as their length and sequence are important for an efficient targeting. The intracellular domain acts as signal transducer. It was shown that the cytoplasmic segment of CD3 zeta plays the principal role due to different functions in activated T-cells and the resting ones. However, this cytoplasmic part cannot activate the resting $\mathrm{T}$ lymphocytes.

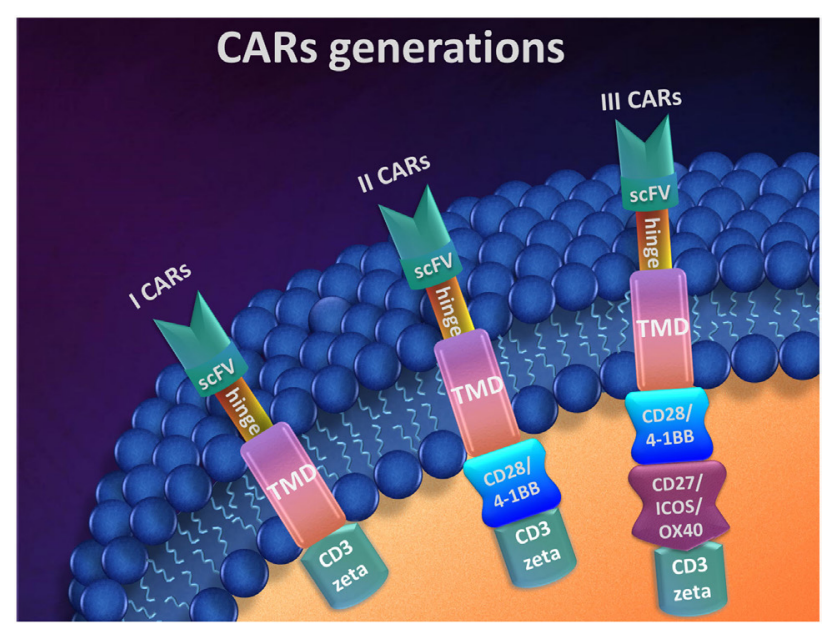

FIGURE 2 | Chimeric antigen receptors (CARs) generations. 
This cytoplasmic part cannot activate the resting T lymphocytes (113). Although the first-generation CARs showed promising results in vitro (114-116), these data emphasized the need of at least secondary signal for the fully activation of T-cells. To overcome these limitations, second- and third-generation CARs were developed. By using a costimulatory domain, T-cell activation was achieved in vitro, with good persistence in vivo (117, 118). Also, incorporation of more potent costimulatory domains enhances T-cells functions in vivo, as shown by later studies (119-121).

Furthermore, the absence of highly specific proteins on the surface of some tumor cells is not a drawback for this therapy because CARs can have different modifications (first generation versus third generation) to increase its antitumor activity and are very specific for cell surface molecules (122-124). These receptors recognize and bind different structures, from protein epitopes to glycolipids and carbohydrates (125).

An optimal target for CAR T-cells would be a tumor-specific antigen. This would be ideal, but in ALL, no tumor-specific antigens are targeted efficiently. The main difference between a normal and leukemia cell is the antigen expression abundance, increased in the malignant one. In B-cell ALL, it is more efficient to develop CAR constructs depending on B-cell lineage, as shown in Figure 3.

By adding an additional costimulatory signaling domain such as CD28 or $4-1 \mathrm{BB}$ at the CD3 zeta intracellular signaling domain, one can build second-generation CARs. Both CD28 and 4-1BB (CD137) costimulatory signaling domains are related with clonal expansion of activated T-cells, being recognized to be related to longtime survival of activated T-cells than CD28 signals $(50,126-128)$. By further adding another two or more costimulatory signaling domains like CD27, CD28, 4-1BB, ICOS, or OX40 at the CD3 zeta intracellular signaling domain, one can build third-generation CARs $(81,129)$. CD27, ICOS, and OX40 (CD134) costimulation with CD28 or $4-1 \mathrm{BB}$ improves T-cell survival (130-132).

Costimulatory signaling from CD28 is associated with improved CAR T-cell expansion and persistence after their

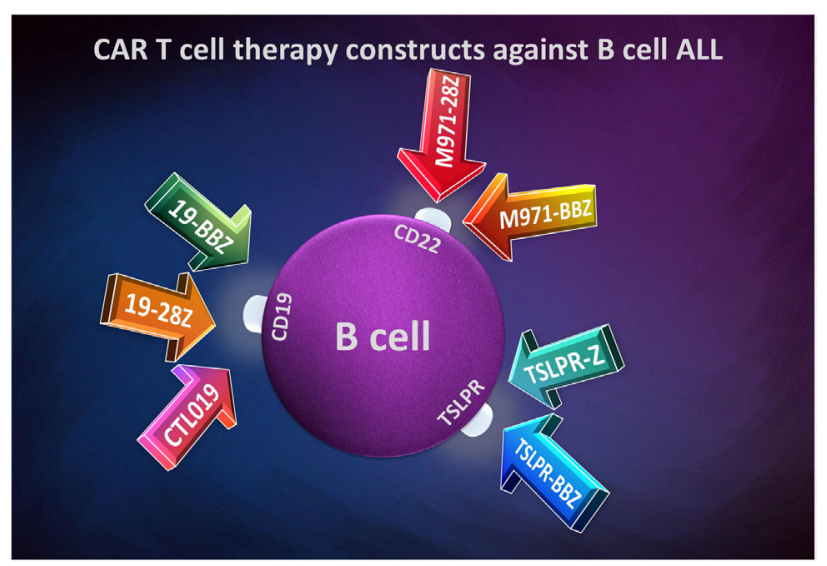

FIGURE 3 | Chimeric antigen receptor T-cell therapy constructs against B-cell acute lymphoblastic leukemia. infusion into the patient's blood stream, with excellent results in indolent B-cell malignancies, as well in ALL. CD28 costimulation is usually provided by antigen-presenting cells and are linked to various signaling molecules of the TNF receptor family such as OX40 and 4-1BB (20). CD28-containing CARs were investigated in a phase I clinical trial in which eight chronic lymphocytic leukemia (CLL) and one ALL patients were recruited (24). Although eight of the patients tolerated the CAR infusion well, one of them had a rapid clinical deterioration and died $48 \mathrm{~h}$ following the infusion. Others developed fever with or without arterial hypotension. One of the CLL patients had a partial response, and none of them had B-cell aplasia. The ALL patient was treated in remission, developed B-cell aplasia even if the other hematopoietic series were recovered, a clinical status that lasted until he received an allogeneic SCT after 8 weeks. For this trial, the persistence of the infused CARs was inversely proportional with the tumor burden, being enhanced by prior cyclophosphamide administration. This is an additional reason for the support of lymphodepletion chemotherapy before CAR infusion.

\section{SECOND-GENERATION CAR CONSTRUCTS FOR HEMATOLOGICAL MALIGNANCIES}

In present-day clinical trials for hematological malignancies, the most widely used CARs for immunotherapy are the secondgeneration CARs because of their enhanced viability and efficiency in vivo $(74,133)$. Even if these CARs show a therapeutic potential in the treatment for ALL, severe side effects are a major drawback including CRS and B-cell aplasia $(116,134)$. Current state-of-the-art CAR design aims at programming T-cells using suicide genes transfer in CAR T-cell constructs (135).

Most of targeting immunotherapies involving CAR T-cell used in B-cell ALL are against the B-cell surface protein CD19. This receptor expresses during $\mathrm{B}$-cell development and is specific to a single-cell lineage. Moreover, this antigen is expressed in almost all B-cell malignancies such as B-cell chronic lymphoblastic leukemia, B-cell ALL, and non-Hodgkin lymphomas. Immunotherapy based on CARs is at its beginnings and various medical centers throughout the world have begun to assess their efficacy both in preclinical setting and in phase I/II clinical trials. Still, sometimes because of different manufacturing and delivery of CARs between various centers, it is somewhat difficult to compare the results obtained between various researchers. This has lead to outcome differences due to the costimulatory sequence in the CAR construct. One such example is the optimization of CD19 CAR T-cell immunotherapy in multicentric clinical trials because of the lack of uniformity of the infused cellular product.

Anti-CD19 CAR T-cell products may vary depending on the institutional design, doses, and T-cell activation and transduction methods. Imai et al. have developed a second-generation CARs, anti-CD19-BB-zeta, by combining an anti-CD19 scFv, a hinge, a CD8 alpha TMD, a CD3 zeta-signaling domain with a $4-1 \mathrm{BB}$ co-signaling domain for B-cell ALL therapy. This CAR construct presented a durable expression due to the retroviral transduction 
mechanism and an efficient cytotoxic activity against ALL cells $(136,137)$. Another example using the 4-1BB co-signaling domain for CD19+ ALL cells is the CTL019 construct, which was obtained using a lentiviral vector. CAR T-cells with this construct were administrated for B-cell ALL patients and showed an increased expansion in vivo more than 1,000 times in comparison to the initial dose injected. Good results are reported as a $90 \%$ complete remission rate in 30 patients with relapsed and refractory B-cell ALL $(110,124)$. CAR-based therapy that involves the 4-1BB co-signaling domain can be of high clinical potential for relapsed $\mathrm{Ph}$-positive ALL patients, as shown by Zhu et al. (138). A negative aspect of this therapy refers to the side effects as described above: B-cell aplasia and CRS $(124,139)$, as well as encephalopathy. Neurological adverse effects have been associated with CAR T-cell activity, all of them being simultaneous or after the CRS. Such side effects include aphasia, confusion, hallucinations, delirium, or even seizures and are thought to be related to CD19 (140-142). Neurological complications following CAR T-cell infusion is closely related to CRS, a systemic inflammatory response incompletely understood so far (43). Similar effects have been described for blinatumomab in Ph-negative relapsed or refractory B-cell ALL, but the mechanism of action is incompletely understood.

By respecting the $\mathrm{CD} 28$ co-signaling domain, the construct was integrated in an additional anti-CD19 second-generation CAR construct named 19-28z. This newly described construct proved good results for relapsed or refractory B-cell ALL patients (143). This therapy was shown to have $88 \%$ complete response (CR) rates in 16 patients with relapsed or refractory B-cell ALL. Still, side effects such as CRS were reported, with high values of C-reactive protein as an indicator of its severity. Another second-generation CAR construct incorporating CD28 signaling domain proved efficiency for 21 chemotherapy-resistant B precursor ALL patients (70\% complete remission rate) without encountering prolonged B-cell aplasia after. In addition, the other side effects such as CRS were reversible (144). CAR T-cell-based therapy represents external stimuli that might be significant on the immune system. Hill et al. have addressed this question and investigated the epidemiology of infections 90 days following CAR T-cell infusion for 133 patients diagnosed with a B-cell malignancy (145). They concluded that the incidence and type of infections are correlated to the patients with B-cell malignancies who have received salvage chemoimmunotherapy. The ones with a greater immunosuppression had a higher risk of infections. Still, life-threatening or rare infections were rare, being present especially in the ones who received lymphodepletion chemotherapy. Thus, efficient strategies to prevent infections must be developed to optimize CAR-T.

In some cases, the responses to an anti-CD19 CAR T-cells immunotherapy are not as good as expected, especially when B-cells lose their receptors expression $(146,147)$. Therefore, the need to identify other suitable targets on B-cells emerged. Other CAR-Ts focus on CD22 surface receptor. The CD22 antigen is another B-cell antigen family member, in fact a Siglec-family lectin, which is expressed during B-cell development and lost upon the differentiation to plasma cells. The tissue distribution of CD22 antigen is similar to CD19 (148). m971 anti-CD22 monoclonal antibody is a part of the derived second-generation CARs (m971$28 \mathrm{z}$ or $\mathrm{m} 971-\mathrm{BBz}$ ) and have showed good results in treating B-cell precursor ALL patients (149).

Some B-cell ALL patients overexpress the thymic stromal lymphopoietin receptor (TSLPR) due to rearrangements in order of translocations or deletions on CRLF2 gene, which encodes it $(150,151)$. This receptor may actually be a new target for developing new CAR constructs. Qin et al. have used in their study two CAR constructs: a first-generation CAR and a second-generation CAR (152). The long one included a CD3 zeta intracellular domain, a 4-1BB co-signaling domain, a CD8 TMD, and the scFvs for TSLPR targeting. The shorter CAR proved a greatest activity than the longer one, even when it was comparatively analyzed with second-generation anti-CD19 and anti-CD22 CAR constructs.

\section{PRECLINICAL MODELS OF CARs IN ALL}

One of the first documented adverse reactions on CAR-T in preclinical murine models is CRS. It has been shown in a murine model that CAR T-cell infusion-associated CRS can be prevented through the administration of the kinase inhibitor ibrutinib (42). Another potential side effect of CAR T-cell use is graft-versus-host disease (GVHD). To the present date, GVHD is not a real concern regarding CAR-T side effects (153). Provasi et al., using zinc finger nucleases against the endogenous TCR $\alpha$ and $\beta$ genes, managed to edit Tg T-cells to express only Willms tumor-1 (WT-1)-specific TCRs in a Hu-PBL-severe combined immunodeficiency (SCID) animal model, a SCID mouse grafted with human peripheral blood lymphocytes, of WT- $1^{+}$leukemia. The results of the study have shown that the mice receiving edited WT- $1^{+}$T-cells developed neither leukemia nor GVHD 50 days postleukemic transplantation, while mice receiving un-edited WT- $1^{+}$T-cells had all succumbed to GVHD and mice that did not receive PBMC all died of leukemia (154). Years later, in two clinical reports, patients who underwent allogeneic SCT also received infusions of anti-CD19 CAR allogeneic T-cells from their initial transplant donors. The first report did not identify any GVHD in any of the 8 transplanted patients (155), while the second report showed that 1 of 20 patients developed a worsening of a pre-existing chronic GVHD (156).

Across the large variety and number of preclinical publications focusing on CAR T-cells, very few of them document toxicity in animal models as it would seem normal with any new compound that has a potential use in a clinical setting. Paradoxically, there are numerous studies reporting the clinical use of CAR T-cells even though their safety has not yet been evaluated extensively in vivo. An explanation for this phenomenon could include factors such as the large variety of engineered CAR cells, the differences between mouse and human physiology and T-cell biology and the differences in drug metabolism capacity in each species. An example that would confirm this hypotheses would be the fact that one in vivo study involves CAR T-cells targeting the Her2/neu antigen, proving the antineoplastic activity and the biological safety of Her2/neu-specific CAR T-cells in transgenic animals with lymphodepletion (157), yet the clinical trial involving the 
same engineered cells showed that one of the patients died due to a massive CRS (158). The majority of preclinical studies investigating CAR T-cells have focused on verifying their specificity and potency for antineoplastic activity, the key advantage of CARs in vivo being the fact that they possess the ability to redirect T-cell effector function without HLA-restriction. The in vivo testing of CARs expresses several drawbacks. First of all, the successful engraftment of T-cells in immunocompromised mice is hard to achieve due to the residual elements of the mouse's innate immune system; another drawback is the fact that even if the engraftment is successful, most of the mice develop GVHD in long-term studies (more than 60 days) (159), which stuns the research on the long-term effects of CAR T-cells in animal models. CAR T-cells target human antigens, which are restricted to transplanted tumor cells in mice, rendering the assessment of their effects on healthy tissues in mice models hard to achieve (46). The humanized NSG mouse has been an indispensable tool for evaluating short-term CAR T-cell activity in vivo. CARs that act against ROR1 for mantle cell lymphoma and CD44v6 for AML and multiple myeloma have been tested in humanized NSG mice extensively $(160,161)$. Humanized mice have been also used to assess the function and efficacy of costimulatory domains such as CD27, ICOS, CD28, and 4-1BB, due to their potential enhanced efficiency in targeting malignancies and augmenting CARs safety $(120,130)$. In a humanized animal model, the Hu-PBL-SCID NSG mouse, engineered T-cells showed the ability to destroy a cancer cell line that expressed prostate tumor antigens (80). Modern genetic engineering methods like messenger RNA transduction have been used to generate CAR NK cells and to successful target a non-Hodgkin's lymphoma in a Hu-PBL-SCID NSG model. The study confirmed that activated expanded peripheral blood NK cell (PBNK) became highly cytolytic, eradicating resistant $\mathrm{CD} 20^{+}$B-leukemia/lymphoma after nucleofection with anti-CD20 CAR messenger RNA (162). CAR-modified PBNKs are anti-CD20 CAR-modified expanded NK cells significantly mediate immunotherapy-resistant B-cell malignancies. Moreover, authorities have approved two clinical studies using CAR-expressing NK cells for the treatment of B-lineage ALL. One of the clinical studies (NCT00995137) is aimed to identify the maximum tolerance dose of genetically modified NK cells for patients with relapsed or refractory B-lineage ALL at St. Jude Children's Research Hospital in Memphis, United States. In this clinical study, allogeneic NK cells were first expanded by co-culture with irradiated $\mathrm{K} 562$ cells that were modified to express membrane-bound IL-15 and 4-1BB ligand (K562mb15-4-1BBL) overexpression of these proteins promotes selective growth of NK cells. The in vitro expanded NK cells were then transduced with vectors encoding a signaling receptor that binds to CD19, which is only expressed on B-lineage ALL cells. A similar study (NCT01974479) performed by the National University Hospital in Singapore investigated the persistence and phenotype of redirected NK cells in participants with residual B-lineage ALL after chemotherapy. In that study, donor NK cells were activated and expanded by K562-mb15-4-1BBL cell line combined with IL-2 and then transduced with vectors encoding a signaling receptor targeting CD19 $(163,164)$.
Even if current animal models for CAR T-cells have a poor predictive nature, these may relate to the biological differences between species, a barrier that could be overcome by developing new humanized mice models. Studies in the last decade have focused mainly on their clinical applications with toxicity being neglected as a main research aim. Most of the clinical studies report toxic effects on these engineered cells, which in turn will cause a stronger will of the researchers to better understand the potential mechanisms of in vivo toxicity by developing better animal models to this purpose.

\section{GENETIC ENGINEERED T-CELLS FOR THE IMMUNOTHERAPY OF ALL}

State-of-the-art therapies for ALL have been developed during last decade, with a special emphasis on the role of immunotherapy and T-cells genetic engineering. The first method regarding T-cells genetic engineering was gene transfer of $\alpha$ and $\beta$ chain subunits of cloned T-cells receptors specific to tumor antigens. The strategy already succeeded for melanoma (165), but it was shown to have limitations in B-cell malignancies because of their restrictions to HLA phenotypes. CAR-T is an attractive targeted immunotherapy, which has proved its potential as an alternative for curing a lot of blood malignancies, especially B-cell ALL.

The outcomes are sometimes different as the different T-cell subsets are different regarding their ability to eliminate the malignant $B$ lymphocyte, even in xenogenic models of the disease (166). This is of crucial importance in B-cell malignancies that have a variable T-cell subset, as is the case of B-cell ALL (51). The overcoming of this problem was attempted by manufacturing CARs from well-defined $\mathrm{CD}^{+}$and $\mathrm{CD} 8^{+}$ subsets (129). Even though the selection of manufacturing is slightly more complex, it allows the infusion of a uniform cellular graft, and thus, it made possible to correlate the CAR dosage and toxicity to disease response properly. In B-cell ALL, CD4 ${ }^{+}$T-cells formulated with either bulk CD8 ${ }^{+} \mathrm{T}$-cells or central memory cells have led to almost universal CR rates in both arms of the study. A high CR rate was later confirmed by other groups that used engineered T-cells from bulk T-cell subsets $(46,52,53)$.

Grupp et al. (45) describe the use of CARs for B-cell ALL in patients with active disease with multiple relapses after chemotherapy. One of the two patients underwent an unrelated cord blood transplant at the time of CAR infusion with PBMC that were $68 \%$ of donor origin, whereas the other patient received autologous cells. Both patients went into remission. The cord blood-transplanted patient had a relapse 8 weeks following the T-cell infusion, with CD19-negative leukemic cells. This suggests that a new leukemic clone emerged and escaped the immune recognition of the CAR. Both patients had a systemic inflammatory syndrome and transient neurological symptoms.

MRD-negative CR is higher, and CAR persistence is longer in $\mathrm{B}$-cell ALL patients who were treated is two clinical trials that used CARs that were different and incorporated 4-1BB-costimulated CARs, when compared to two other trials that incorporated a CD28-mediated costimulation $(46,53)$. These differences in the 
CAR construct, which included the scFv, the spacer, or the TMD, were additional to other differences in trial comparison such as the clinical characteristics of the patients, the lymphodepletion chemotherapy, or the schedule of treatments. From all of these differences, the choice of lymphodepletion chemotherapy may have the most profound impact on the transferred T-cell expansion and persistence in the patient. This impact might be due to IL-7 and IL-15, highly used in CAR-based immunotherapy $(167,168)$. B-cell ALL patients who were treated with cyclophosphamide or fludarabine lymphodepletion before CAR infusion had a good T-cell expansion and persistence in vivo, whereas the ones who had received cyclophosphamide with fludarabine had a shorter in vivo T-cell expansion.

For patients who undergo an allogeneic SCT, there is a theoretical risk of inducing graft-versus-host-disease by the polyclonal activated T-cells. The alternative approach to replace polyclonal CAR T-cells is the transferring of the CAR into T lymphocytes with a well-defined specificity through their native antigen receptor. Thus, it will exclude the alloreactive cells (169-171). This principle was assessed both in the preclinical setting and in a trial for neuroblastoma, and the patients were treated with both polyclonal T-cells and EBV-specific T-cells genetically modified to express the GD2 neuroblastoma antigen $(172,173)$. The results were afterward confirmed in B-cell hematological malignancies in a trial that included high-risk CLL, transformed CLL, and ALL. All of the patients had relapsed or were at high risk of relapse after a previous allogeneic SCT (155). The CARs were administered without preinfusion chemotherapy. T lymphocytes were activated and expanded with CMV, EBV, and adenoviral antigens and only afterward transduced with the CD19 CARs, thus resulting cells active against all three types of viruses due to their native TCR. Eight patients were treated and infusions were tolerated, without any systemic inflammation or signs of acute GVHD. The CARs were detected in the peripheral blood of all patients 12 weeks following the infusion, with objective responses achieved in 2 of 8 patients, 1 complete remission and 1 partial remission. Still, both remissions were transient. It is worthwhile to mention that the patients for whom long-term follow-up was possible, no B-cell aplasia was recorded, as well as no agammaglobulinemia, suggesting that allogeneic virus-specific T-cells that express CD19 CAR are well tolerated, efficient against B-cell malignancies up to a certain point.

The tumor microenvironment plays an important role in the initiation and progression of a malignancy, including resistance to chemotherapy $(137,138)$, as previously shown by our group. Lim and June have addressed this issue, linking CAR-T to targeting the malignant microenvironment as even if engineered T-cells may specifically recognize and target a cancer cell, the microenvironment has a suppressive effect on the CAR T-cells, thus limiting its efficacy (139). Thus, combination therapy with checkpoint inhibitors may provide a viable solution for enhancing the antitumor effect of the CAR T-cells, as it was proven by the team of O'Rourke et al. in solid malignancies (140). A good strategy would be to develop the so-called armored CARs, which also express the very efficient cytokine IL-12, which has a pleiotropic on both innate and adaptive T lymphocytes (141). To further augment the antitumor activity, the fourth-generation CAR that contains a transduction domain to promote production of a T-cell-activating cytokine such as IL-12 (so-called armored CAR T) are currently being researched $(174,175)$. The choice of the "armor" agent is based on the knowledge of the tumor microenvironment and the roles of other elements of the innate and adaptive immune system. Although there are several variants of armored CAR T-cells under investigation, here, we focus on three unique approaches using IL-12, CD40L, and 4-1BBL. These agents have been shown to further enhance CAR T-cell efficacy and persistence in the face of a hostile tumor microenvironment via different mechanisms. Other molecules that could be useful in combination with CARs, which could also be used to remodel the malignant microenvironment, is the synNotch receptor system, which may aid in producing specific secreting payloads in response to the recognition in a target antigen, thus turning the CARs into the so-called pharmacytes (142). The synNotch system is a flexible method of programming cells to find and respond to molecular signals of disease. The highly customizable system, known as synNotch, can be used to deliver therapeutic molecules to a disease site or modulate local immune activity. Roybal et al. have used synNotch to instruct immune cells to carry out specific activities in the presence of their targets, such as delivering therapeutic antibodies to tumors or triggering the release of signaling molecules that can dampen overactive immune responses (176). The synNotch system is an adaptation of a naturally occurring receptor molecule called Notch, which facilitates critical cell-to-cell communications in most organisms. Notch receptors are embedded in cells' outer membranes, with functional components protruding into both the cell's interior and its external environment. When the exterior part of a Notch receptor connects with its molecular partner, its interior end is freed from the rest of the molecule and moves to the cell's nucleus, where it activates specific genes.

Thus, CAR T-cells may potentially represent a new age in cancer immunotherapy, with endless possibilities that must be investigated in hematology and oncology, both in the preclinical setting and in phase I to phase III clinical trials, before being approved as standard of care.

\section{CONCLUSION}

Chimeric antigen receptor T-cells have been reported to show an exceptional activity against B-cell malignancies, may it be CLL, non-Hodgkin's lymphomas, or ALL in the preclinical setting, as well as in early clinical trials. Despite the excellent results obtained so far, intriguing questions related to the engineering and their clinical activities have emerged. We still do not know exactly the optimal method for transferring CARs into T-cells, may be it lentiviral or retroviral, or which specific costimulatory domain to use. CARs are also related to severe side effects such as tumor lysis syndrome or release of inflammatory cytokines, as well as their effectiveness in replacing the hematopoietic SCT altogether or being just a bridge to transplant as consolidation therapy. Still, the results of CAR T-cells were far from being imaginable 10 years ago, and numerous trials are expanding these 
opportunities and answering these questions. Up to this point, we can only state that CAR T-cells represent an interesting option for treating B-cell ALL, which became one of standard of cares in this type of cancer.

\section{AUTHOR CONTRIBUTIONS}

All authors have contributed to the design of the review and to writing of the manuscript.

\section{REFERENCES}

1. Hunger SP, Mullighan CG. Acute lymphoblastic leukemia in children. N Engl J Med (2015) 373(16):1541-52. doi:10.1056/NEJMra1400972

2. Herold T, Baldus CD, Gokbuget N. Ph-like acute lymphoblastic leukemia in older adults. N Engl J Med (2014) 371(23):2235. doi:10.1056/ NEJMc1412123

3. Jones L, Carol H, Evans K, Richmond J, Houghton PJ, Smith MA, et al. A review of new agents evaluated against pediatric acute lymphoblastic leukemia by the pediatric preclinical testing program. Leukemia (2016) 30(11):2133-41. doi:10.1038/leu.2016.192

4. Cortelazzo S, Ferreri A, HoelzerD, Ponzoni M. Lymphoblasticlymphoma. Crit Rev Oncol Hematol (2017) 113:304-17. doi:10.1016/j.critrevonc.2017.03.020

5. Graubert TA. A call to action for acute lymphoblastic leukemia. $N$ Engl J Med (2014) 371(11):1064-6. doi:10.1056/NEJMe1407477

6. Roberts KG, Li Y, Payne-Turner D, Harvey RC, Yang YL, Pei D, et al. Targetable kinase-activating lesions in Ph-like acute lymphoblastic leukemia. N Engl J Med (2014) 371(11):1005-15. doi:10.1056/NEJMoa1403088

7. Terwilliger T, Abdul-Hay M. Acute lymphoblastic leukemia: a comprehensive review and 2017 update. Blood Cancer J (2017) 7(6):e577. doi:10.1038/ bcj.2017.53

8. Baranger L, Cuccuini W, Lefebvre C, Luquet I, Perot C, Radford I, et al. Cytogenetics in the management of children and adult acute lymphoblastic leukemia (ALL): an update by the Groupe francophone de cytogenetique hematologique (GFCH). Ann Biol Clin (2016) 74(5):547-60. doi:10.1684/ abc. 2016.1176

9. Burke MJ. How to manage asparaginase hypersensitivity in acute lymphoblastic leukemia. Future Oncol (2014) 10(16):2615-27. doi:10.2217/ fon. 14.138

10. Dhawan R, Marks DI. Who should receive a transplant for acute lymphoblastic leukaemia? Curr Hematol Malig Rep (2017) 12(2):143-52. doi:10.1007/ s11899-017-0371-4

11. Hoelzer D, Thiel E, Loffler H, Buchner T, Ganser A, Heil G, et al. Prognostic factors in a multicenter study for treatment of acute lymphoblastic leukemia in adults. Blood (1988) 71(1):123-31.

12. Iacobucci I, Mullighan CG. Genetic basis of acute lymphoblastic leukemia. J Clin Oncol (2017) 35(9):975-83. doi:10.1200/JCO.2016.70.7836

13. Brown PA, Shah B, Fathi A, Wieduwilt M, Advani A, Aoun P, et al. NCCN guidelines insights: acute lymphoblastic leukemia, version 1.2017. J Natl Compr Canc Netw (2017) 15(9):1091-102. doi:10.6004/jnccn.2017.0147

14. Oskarsson T, Soderhall S, Arvidson J, Forestier E, Montgomery S, Bottai M, et al. Relapsed childhood acute lymphoblastic leukemia in the Nordic countries: prognostic factors, treatment and outcome. Haematologica (2016) 101(1):68-76. doi:10.3324/haematol.2015.131680

15. Liedtke M, Dunn T, Dinner S, Coutre SE, Berube C, Gotlib J, et al. Salvage therapy with mitoxantrone, etoposide and cytarabine in relapsed or refractory acute lymphoblastic leukemia. Leuk Res (2014) 38(12):1441-5. doi:10.1016/j.leukres.2014.09.018

16. Yanada M, Naoe T. Imatinib combined chemotherapy for Philadelphia chromosome-positive acute lymphoblastic leukemia: major challenges in current practice. Leuk Lymphoma (2006) 47(9):1747-53. doi:10.1080/ 10428190600634085

17. Rousselot P, Coude MM, Gokbuget N, Gambacorti Passerini C, Hayette S, Cayuela JM, et al. Dasatinib and low-intensity chemotherapy in elderly patients with Philadelphia chromosome-positive ALL. Blood (2016) 128(6):774-82. doi:10.1182/blood-2016-02-700153

\section{FUNDING}

CT received funding from the Romanian Research Ministry, contracts PN-II-RU-TE-2014-4-1783 (awarded to Young Research Teams) and CNFIS-FDI-2017-1350 (awarded to Institutional development funds), as well as from an international collaboration grant between Romania and P.R. China, contract 57 BM/2016. Both DD and CT received funding from the Romanian Research Ministry grants for postdoctoral research 2017-2018.

18. Bassan R, Spinelli O, Oldani E, Intermesoli T, Tosi M, Peruta B, et al. Improved risk classification for risk-specific therapy based on the molecular study of minimal residual disease (MRD) in adult acute lymphoblastic leukemia (ALL). Blood (2009) 113(18):4153-62. doi:10.1182/blood-2008-11-185132

19. Berry DA, Zhou S, Higley H, Mukundan L, Fu S, Reaman GH, et al. Association of minimal residual disease with clinical outcome in pediatric and adult acute lymphoblastic leukemia: a meta-analysis. JAMA Oncol (2017) 3(7):e170580. doi:10.1001/jamaoncol.2017.0580

20. Paietta E. Assessing minimal residual disease (MRD) in leukemia: a changing definition and concept? Bone Marrow Transplant (2002) 29(6):459-65. doi:10.1038/sj.bmt.1703388

21. Chen X, Wood BL. Monitoring minimal residual disease in acute leukemia: technical challenges and interpretive complexities. Blood Rev (2017) 31(2):63-75. doi:10.1016/j.blre.2016.09.006

22. Salari F, Shahjahani M, Shahrabi S, Saki N. Minimal residual disease in acute lymphoblastic leukemia: optimal methods and clinical relevance, pitfalls and recent approaches. Med Oncol (2014) 31(11):266. doi:10.1007/ s12032-014-0266-3

23. Schrappe M. Detection and management of minimal residual disease in acute lymphoblastic leukemia. Hematology Am Soc Hematol Educ Program (2014) 2014(1):244-9. doi:10.1182/asheducation-2014.1.244

24. Friberg G, Reese D. Blinatumomab (Blincyto(R)); lessons learned from the bispecific t-cell engager $(\operatorname{BiTE}(\mathrm{R}))$ in acute lymphocytic leukemia (ALL). Ann Oncol (2017) 28(8):2009-12. doi:10.1093/annonc/mdx150

25. Fitzgerald JC, Weiss SL, Maude SL, Barrett DM, Lacey SF, Melenhorst JJ, et al. Cytokine release syndrome after chimeric antigen receptor $\mathrm{T}$ cell therapy for acute lymphoblastic leukemia. Crit Care Med (2017) 45(2):e124-31. doi:10.1097/CCM.0000000000002053

26. Nagy-Simon T, Tatar AS, Craciun AM, Vulpoi A, Jurj MA, Florea A, et al. Antibody conjugated, raman tagged hollow gold-silver nanospheres for specific targeting and multimodal Dark-Field/SERS/Two Photon-FLIM imaging of CD19(+) B lymphoblasts. ACS Appl Mater Interfaces (2017) 9(25):21155-68. doi:10.1021/acsami.7b05145

27. Tatar AS, Nagy-Simon T, Tomuleasa C, Boca S, Astilean S. Nanomedicine approaches in acute lymphoblastic leukemia. JControl Release (2016) 238:123-38. doi:10.1016/j.jconrel.2016.07.035

28. Kantarjian H, Thomas D, Jorgensen J, Jabbour E, Kebriaei P, Rytting M, et al. Inotuzumab ozogamicin, an anti-CD22-calecheamicin conjugate, for refractory and relapsed acute lymphocytic leukaemia: a phase 2 study. Lancet Oncol (2012) 13(4):403-11. doi:10.1016/S1470-2045(11)70386-2

29. Kantarjian HM, DeAngelo DJ, Stelljes M, Martinelli G, Liedtke M, Stock W, et al. Inotuzumab ozogamicin versus standard therapy for acute lymphoblastic leukemia. N Engl J Med (2016) 375(8):740-53. doi:10.1056/ NEJMoa 1509277

30. Monjezi R, Miskey C, Gogishvili T, Schleef M, Schmeer M, Einsele H, et al. Enhanced CAR T-cell engineering using non-viral sleeping beauty transposition from minicircle vectors. Leukemia (2017) 31(1):186-94. doi:10.1038/ leu.2016.180

31. Yeku O, Li X, Brentjens RJ. Adoptive T-cell therapy for solid tumors. Am Soc Clin Oncol Educ Book (2017) 37:193-204. doi:10.14694/EDBK_180328

32. Pan J, Yang JF, Deng BP, Zhao XJ, Zhang X, Lin YH, et al. High efficacy and safety of low-dose CD19-directed CAR-T cell therapy in 51 refractory or relapsed B acute lymphoblastic leukemia patients. Leukemia (2017) 31(12):2587-93. doi:10.1038/leu.2017.145

33. Gardner RA, Finney O, Annesley C, Brakke H, Summers C, Leger $\mathrm{K}$, et al. Intent-to-treat leukemia remission by CD19 CAR T cells of 
defined formulation and dose in children and young adults. Blood (2017) 129(25):3322-31. doi:10.1182/blood-2017-02-769208

34. Bonifant CL, Jackson HJ, Brentjens RJ, Curran KJ. Toxicity and management in CAR T-cell therapy. Mol Ther Oncolytics (2016) 3:16011. doi:10.1038/ mto.2016.11

35. Scholler J, Brady TL, Binder-Scholl G, Hwang WT, Plesa G, Hege KM, et al. Decade-long safety and function of retroviral-modified chimeric antigen receptor T cells. Sci Transl Med (2012) 4(132):132ra53. doi:10.1126/ scitranslmed. 3003761

36. Porter DL, Levine BL, Kalos M, Bagg A, June CH. Chimeric antigen receptor-modified T cells in chronic lymphoid leukemia. $N$ Engl J Med (2011) 365(8):725-33. doi:10.1056/NEJMoa1103849

37. Klebanoff CA, Gattinoni L, Restifo NP. Sorting through subsets: which T-cell populations mediate highly effective adoptive immunotherapy? J Immunother (2012) 35(9):651-60. doi:10.1097/CJI.0b013e31827806e6

38. Luskin MR, DeAngelo DJ. Chimeric antigen receptor therapy in acute lymphoblastic leukemia clinical practice. Curr Hematol Malig Rep (2017) 12(4):370-9. doi:10.1007/s11899-017-0394-x

39. Albring JC, Inselmann S, Sauer T, Schliemann C, Altvater B, Kailayangiri S, et al. PD-1 checkpoint blockade in patients with relapsed AML after allogeneic stem cell transplantation. Bone Marrow Transplant (2017) 52(2):317-20. doi:10.1038/bmt.2016.274

40. Frey NV, Porter DL. The promise of chimeric antigen receptor T-cell therapy. Oncology (Williston Park) (2016) 30(10):880-8.

41. Lee DW, Gardner R, Porter DL, Louis CU, Ahmed N, Jensen M, et al. Current concepts in the diagnosis and management of cytokine release syndrome. Blood (2014) 124(2):188-95. doi:10.1182/blood-2014-05-552729

42. Ruella M, Kenderian SS, Shestova O, Klichinsky M, Melenhorst JJ, Wasik MA, et al. Kinase inhibitor ibrutinib to prevent cytokine-release syndrome after anti-CD19 chimeric antigen receptor T cells for B-cell neoplasms. Leukemia (2017) 31(1):246-8. doi:10.1038/leu.2016.262

43. Brudno JN, Kochenderfer JN. Toxicities of chimeric antigen receptor T cells: recognition and management. Blood (2016) 127(26):3321-30. doi:10.1182/ blood-2016-04-703751

44. Chatenoud L, Ferran C, Legendre C, Thouard I, Merite S, Reuter A, et al. In vivo cell activation following OKT3 administration. Systemic cytokine release and modulation by corticosteroids. Transplantation (1990) 49(4):697-702. doi:10.1097/00007890-199004000-00009

45. Grupp SA, Kalos M, Barrett D, Aplenc R, Porter DL, Rheingold SR, et al. Chimeric antigen receptor-modified $\mathrm{T}$ cells for acute lymphoid leukemia. N Engl J Med (2013) 368(16):1509-18. doi:10.1056/NEJMoa1215134

46. Davila ML, Riviere I, Wang X, Bartido S, Park J, Curran K, et al. Efficacy and toxicity management of 19-28z CAR T cell therapy in B cell acute lymphoblastic leukemia. Sci Transl Med (2014) 6(224):224ra25. doi:10.1126/ scitranslmed. 3008226

47. Morgan RA, Yang JC, Kitano M, Dudley ME, Laurencot CM, Rosenberg SA. Case report of a serious adverse event following the administration of $\mathrm{T}$ cells transduced with a chimeric antigen receptor recognizing ERBB2. Mol Ther (2010) 18(4):843-51. doi:10.1038/mt.2010.24

48. Linette GP, Stadtmauer EA, Maus MV, Rapoport AP, Levine BL, Emery L, et al. Cardiovascular toxicity and titin cross-reactivity of affinity-enhanced T cells in myeloma and melanoma. Blood (2013) 122(6):863-71. doi:10.1182/ blood-2013-03-490565

49. Morgan RA, Chinnasamy N, Abate-Daga D, Gros A, Robbins PF, Zheng Z, et al. Cancer regression and neurological toxicity following anti-MAGE-A3 TCR gene therapy. J Immunother (2013) 36(2):133-51. doi:10.1097/ CJI.0b013e3182829903

50. Porter DL, Hwang WT, Frey NV, Lacey SF, Shaw PA, Loren AW, et al. Chimeric antigen receptor T cells persist and induce sustained remissions in relapsed refractory chronic lymphocytic leukemia. Sci Transl Med (2015) 7(303):303ra139. doi:10.1126/scitranslmed.aac5415

51. Turtle CJ, Hanafi LA, Berger C, Gooley TA, Cherian S, Hudecek M, et al. CD19 CAR-T cells of defined CD4+:CD8+ composition in adult B cell all patients. J Clin Invest (2016) 126(6):2123-38. doi:10.1172/JCI85309

52. Maude SL, Frey N, Shaw PA, Aplenc R, Barrett DM, Bunin NJ, et al. Chimeric antigen receptor $\mathrm{T}$ cells for sustained remissions in leukemia. N Engl J Med (2014) 371(16):1507-17. doi:10.1056/NEJMoa1407222

53. Lee DW, Kochenderfer JN, Stetler-Stevenson M, Cui YK, Delbrook C, Feldman SA, et al. T cells expressing CD19 chimeric antigen receptors for acute lymphoblastic leukaemia in children and young adults: a phase 1 dose-escalation trial. Lancet (2015) 385(9967):517-28. doi:10.1016/ S0140-6736(14)61403-3

54. Singh N, Hofmann TJ, Gershenson Z, Levine BL, Grupp SA, Teachey DT, et al. Monocyte lineage-derived IL-6 does not affect chimeric antigen receptor T-cell function. Cytotherapy (2017) 19(7):867-80. doi:10.1016/j. jcyt.2017.04.001

55. Teachey DT, Lacey SF, Shaw PA, Melenhorst JJ, Maude SL, Frey N, et al. Identification of predictive biomarkers for cytokine release syndrome after chimeric antigen receptor T-cell therapy for acute lymphoblastic leukemia. Cancer Discov (2016) 6(6):664-79. doi:10.1158/2159-8290. CD-16-0040

56. Kado R, Sanders G, McCune WJ. Diagnostic and therapeutic considerations in patients with hypogammaglobulinemia after rituximab therapy. Curr Opin Rheumatol (2017) 29(3):228-33. doi:10.1097/BOR.0000000000000377

57. Kochenderfer JN, Somerville RPT, Lu T, Yang JC, Sherry RM, Feldman SA, et al. Long-duration complete remissions of diffuse large B cell lymphoma after anti-CD19 chimeric antigen receptor T cell therapy. Mol Ther (2017) 25(10):2245-53. doi:10.1016/j.ymthe.2017.07.004

58. Kalos M, Levine BL, Porter DL, Katz S, Grupp SA, Bagg A, et al. T cells with chimeric antigen receptors have potent antitumor effects and can establish memory in patients with advanced leukemia. Sci Transl Med (2011) 3(95):95ra73. doi:10.1126/scitranslmed.3002842

59. Agostini C, Blau IW, Kimby E, Plesner T. Prophylactic immunoglobulin therapy in secondary immune deficiency - an expert opinion. Expert Rev Clin Immunol (2016) 12(9):921-6. doi:10.1080/1744666X.2016. 1208085

60. Aguilar C, Malphettes M, Donadieu J, Chandesris O, Coignard-Biehler H, Catherinot E, et al. Prevention of infections during primary immunodeficiency. Clin Infect Dis (2014) 59(10):1462-70. doi:10.1093/cid/ciu646

61. Golumba-Nagy V, Kuehle J, Abken H. Genetic modification of t cells with chimeric antigen receptors: a laboratory Manual. Hum Gene Ther Methods (2017) 28(6):302-9. doi:10.1089/hgtb.2017.083

62. Maude SL, Teachey DT, Porter DL, Grupp SA. CD19-targeted chimeric antigen receptor T-cell therapy for acute lymphoblastic leukemia. Blood (2015) 125(26):4017-23. doi:10.1182/blood-2014-12-580068

63. Zhu Y, Tan Y, Ou R, Zhong Q, Zheng L, Du Y, et al. Anti-CD19 chimeric antigen receptor-modified T cells for B-cell malignancies: a systematic review of efficacy and safety in clinical trials. Eur J Haematol (2016) 96(4):389-96. doi:10.1111/ejh.12602

64. An N, Tao Z, Li S, Xing H, Tang K, Tian Z, et al. Construction of a new anti-CD19 chimeric antigen receptor and the anti-leukemia function study of the transduced T cells. Oncotarget (2016) 7(9):10638-49. doi:10.18632/ oncotarget.7079

65. Qian L, Li D, Ma L, He T, Qi F, Shen J, et al. The novel anti-CD19 chimeric antigen receptors with humanized $\mathrm{scFv}$ (single-chain variable fragment) trigger leukemia cell killing. Cell Immunol (2016) 30(4-305):49-54. doi:10.1016/j. cellimm.2016.03.003

66. Rodgers DT, Mazagova M, Hampton EN, Cao Y, Ramadoss NS, Hardy IR, et al. Switch-mediated activation and retargeting of CAR-T cells for B-cell malignancies. Proc Natl Acad Sci U S A (2016) 113(4):E459-68. doi:10.1073/ pnas. 1524155113

67. Ma JS, Kim JY, Kazane SA, Choi SH, Yun HY, Kim MS, et al. Versatile strategy for controlling the specificity and activity of engineered T cells. Proc Natl Acad Sci U S A (2016) 113(4):E450-8. doi:10.1073/pnas.1524193113

68. Chira S, Jackson CS, Oprea I, Ozturk F, Pepper MS, Diaconu I, et al. Progresses towards safe and efficient gene therapy vectors. Oncotarget (2015) 6(31):30675-703. doi:10.18632/oncotarget.5169

69. Villadangos JA. Antigen-specific impairment of adoptive T-cell therapy against cancer: players, mechanisms, solutions and a hypothesis. Immunol Rev (2016) 272(1):169-82. doi:10.1111/imr.12433

70. Yoon AR, Hong J, Yun CO. A vesicular stomatitis virus glycoprotein epitope-incorporated oncolytic adenovirus overcomes CAR-dependency and shows markedly enhanced cancer cell killing and suppression of tumor growth. Oncotarget (2015) 6(33):34875-91. doi:10.18632/ oncotarget.5332

71. Arina A, Bronte V. Myeloid-derived suppressor cell impact on endogenous and adoptively transferred T cells. Curr Opin Immunol (2015) 33:120-5. doi:10.1016/j.coi.2015.02.006 
72. Marino MP, Panigaj M, Ou W, Manirarora J, Wei CH, Reiser J. A scalable method to concentrate lentiviral vectors pseudotyped with measles virus glycoproteins. Gene Ther (2015) 22(3):280-5. doi:10.1038/gt.2014.125

73. Frecha C, Levy C, Cosset FL, Verhoeyen E. Advances in the field of lentivector-based transduction of T and B lymphocytes for gene therapy. Mol Ther (2010) 18(10):1748-57. doi:10.1038/mt.2010.178

74. Wang X, Riviere I. Clinical manufacturing of CAR T cells: foundation of a promising therapy. Mol Ther Oncolytics (2016) 3:16015. doi:10.1038/ mto.2016.15

75. Brentjens R, Yeh R, Bernal Y, Riviere I, Sadelain M. Treatment of chronic lymphocytic leukemia with genetically targeted autologous $\mathrm{T}$ cells: case report of an unforeseen adverse event in a phase I clinical trial. Mol Ther (2010) 18(4):666-8. doi:10.1038/mt.2010.31

76. Kebriaei P, Singh H, Huls MH, Figliola MJ, Bassett R, Olivares S, et al. Phase I trials using sleeping beauty to generate CD19-specific CAR T cells. J Clin Invest (2016) 126(9):3363-76. doi:10.1172/JCI86721

77. Yong CSM, Dardalhon V, Devaud C, Taylor N, Darcy PK, Kershaw MH. CAR T-cell therapy of solid tumors. Immunol Cell Biol (2017) 95(4):356-63. doi:10.1038/icb.2016.128

78. Brown CE, Alizadeh D, Starr R, Weng L, Wagner JR, Naranjo A, et al. Regression of glioblastoma after chimeric antigen receptor T-cell therapy. N Engl J Med (2016) 375(26):2561-9. doi:10.1056/NEJMoa1610497

79. Hinrichs CS, Restifo NP. Reassessing target antigens for adoptive T-cell therapy. Nat Biotechnol (2013) 31(11):999-1008. doi:10.1038/nbt.2725

80. Kloss CC, Condomines M, Cartellieri M, Bachmann M, Sadelain M. Combinatorial antigen recognition with balanced signaling promotes selective tumor eradication by engineered T cells. Nat Biotechnol (2013) 31(1):71-5. doi:10.1038/nbt.2459

81. Dotti G, Gottschalk S, Savoldo B, Brenner MK. Design and development of therapies using chimeric antigen receptor-expressing $\mathrm{T}$ cells. Immunol Rev (2014) 257(1):107-26. doi:10.1111/imr.12131

82. Wang Z, Wu Z, Liu Y, Han W. New development in CAR-T cell therapy. J Hematol Oncol (2017) 10(1):53. doi:10.1186/s13045-017-0423-1

83. Tamada K, Geng D, Sakoda Y, Bansal N, Srivastava R, Li Z, et al. Redirecting gene-modified $\mathrm{T}$ cells toward various cancer types using tagged antibodies. Clin Cancer Res (2012) 18(23):6436-45. doi:10.1158/1078-0432. CCR-12-1449

84. Newick K, O'Brien S, Moon E, Albelda SM. CAR T cell therapy for solid tumors. Annu Rev Med (2017) 68:139-52. doi:10.1146/annurev-med-062315120245

85. Juillerat A, Marechal A, Filhol JM, Valton J, Duclert A, Poirot L, et al. Design of chimeric antigen receptors with integrated controllable transient functions. Sci Rep (2016) 6:18950. doi:10.1038/srep18950

86. Wu CY, Roybal KT, Puchner EM, Onuffer J, Lim WA. Remote control of therapeutic $\mathrm{T}$ cells through a small molecule-gated chimeric receptor. Science (2015) 350(6258):aab4077. doi:10.1126/science.aab4077

87. Di Stasi A, Tey SK, Dotti G, Fujita Y, Kennedy-Nasser A, Martinez C, et al. Inducible apoptosis as a safety switch for adoptive cell therapy. $N$ Engl J Med (2011) 365(18):1673-83. doi:10.1056/NEJMoa1106152

88. Turtle CJ, Hanafi LA, Berger C, Hudecek M, Pender B, Robinson E, et al. Immunotherapy of non-Hodgkin's lymphoma with a defined ratio of CD8+ and CD4+ CD19-specific chimeric antigen receptor-modified T cells. Sci Transl Med (2016) 8(355):355ra116. doi:10.1126/scitranslmed.aaf8621

89. Desnoyers LR, Vasiljeva O, Richardson JH, Yang A, Menendez EE, Liang TW, et al. Tumor-specific activation of an EGFR-targeting probody enhances therapeutic index. Sci Transl Med (2013) 5(207):207ra144. doi:10.1126/ scitranslmed.3006682

90. Caruso HG, Hurton LV, Najjar A, Rushworth D, Ang S, Olivares S, et al. Tuning sensitivity of CAR to EGFR density limits recognition of normal tissue while maintaining potent antitumor activity. Cancer Res (2015) 75(17):3505-18. doi:10.1158/0008-5472.CAN-15-0139

91. Roybal KT, Rupp LJ, Morsut L, Walker WJ, McNally KA, Park JS, et al. Precision tumor recognition by $\mathrm{T}$ cells with combinatorial antigen-sensing circuits. Cell (2016) 164(4):770-9. doi:10.1016/j.cell.2016.01.011

92. Fedorov VD, Themeli M, Sadelain M. PD-1- and CTLA-4-based inhibitory chimeric antigen receptors (iCARs) divert off-target immunotherapy responses. Sci Transl Med (2013) 5(215):215ra172. doi:10.1126/ scitranslmed.3006597
93. Wei Y, Tsang CK, Zheng XF. Mechanisms of regulation of RNA polymerase III-dependent transcription by TORC1. EMBO J (2009) 28(15):2220-30. doi:10.1038/emboj.2009.179

94. Ranzani M, Cesana D, Bartholomae CC, Sanvito F, Pala M, Benedicenti F, et al. Lentiviral vector-based insertional mutagenesis identifies genes associated with liver cancer. Nat Methods (2013) 10(2):155-61. doi:10.1038/ nmeth. 2331

95. Jin C, Fotaki G, Ramachandran M, Nilsson B, Essand M, Yu D. Safe engineering of CAR T cells for adoptive cell therapy of cancer using long-term episomal gene transfer. EMBO Mol Med (2016) 8(7):702-11. doi:10.15252/emmm.201505869

96. Belur LR, Frandsen JL, Dupuy AJ, Ingbar DH, Largaespada DA, Hackett PB, et al. Gene insertion and long-term expression in lung mediated by the sleeping beauty transposon system. Mol Ther (2003) 8(3):501-7. doi:10.1016/ S1525-0016(03)00211-9

97. Aronovich EL, Bell JB, Belur LR, Gunther R, Koniar B, Erickson DC, et al. Prolonged expression of a lysosomal enzyme in mouse liver after sleeping beauty transposon-mediated gene delivery: implications for non-viral gene therapy of mucopolysaccharidoses. J Gene Med (2007) 9(5):403-15. doi:10.1002/jgm.1028

98. Hudecek M, Izsvak Z, Johnen S, Renner M, Thumann G, Ivics Z. Going non-viral: the sleeping beauty transposon system breaks on through to the clinical side. Crit Rev Biochem Mol Biol (2017) 52(4):355-80. doi:10.1080/1 0409238.2017.1304354

99. Belancio VP, Hedges DJ, Deininger P. Mammalian non-LTR retrotransposons: for better or worse, in sickness and in health. Genome Res (2008) 18(3):343-58. doi:10.1101/gr.5558208

100. Sadelain M, Riviere I, Riddell S. Therapeutic T cell engineering. Nature (2017) 545(7655):423-31. doi:10.1038/nature22395

101. Eyquem J, Mansilla-Soto J, Giavridis T, van der Stegen SJ, Hamieh M, Cunanan KM, et al. Targeting a CAR to the TRAC locus with CRISPR/Cas9 enhances tumour rejection. Nature (2017) 543(7643):113-7. doi:10.1038/ nature 21405

102. Sanchez-Rivera FJ, Jacks T. Applications of the CRISPR-Cas9 system in cancer biology. Nat Rev Cancer (2015) 15(7):387-95. doi:10.1038/nrc3950

103. Chira S, Gulei D, Hajitou A, Zimta AA, Cordelier P, Berindan-Neagoe I. CRISPR/Cas9: transcending the reality of genome editing. Mol Ther Nucleic Acids (2017) 7:211-22. doi:10.1016/j.omtn.2017.04.001

104. Rupp LJ, Schumann K, Roybal KT, Gate RE, Ye CJ, Lim WA, et al. CRISPR/ Cas9-mediated PD-1 disruption enhances anti-tumor efficacy of human chimeric antigen receptor T cells. Sci Rep (2017) 7(1):737. doi:10.1038/ s41598-017-00462-8

105. Cyranoski D. CRISPR gene-editing tested in a person for the first time. Nature (2016) 539(7630):479. doi:10.1038/nature.2016.20988

106. Kawalekar OU, RS OC, Fraietta JA, Guo L, McGettigan SE, Posey AD Jr, et al. Distinct signaling of coreceptors regulates specific metabolism pathways and impacts memory development in CAR T cells. Immunity (2016) 44(2):380-90. doi:10.1016/j.immuni.2016.01.021

107. Klebanoff CA, Scott CD, Leonardi AJ, Yamamoto TN, Cruz AC, Ouyang C, et al. Memory $\mathrm{T}$ cell-driven differentiation of naive cells impairs adoptive immunotherapy. J Clin Invest (2016) 126(1):318-34. doi:10.1172/JCI81217

108. Gattinoni L, Zhong XS, Palmer DC, Ji Y, Hinrichs CS, Yu Z, et al. Wnt signaling arrests effector $\mathrm{T}$ cell differentiation and generates CD8+ memory stem cells. Nat Med (2009) 15(7):808-13. doi:10.1038/nm.1982

109. Abate-Daga D, Davila ML. CAR models: next-generation CAR modifications for enhanced T-cell function. Mol Ther Oncolytics (2016) 3:16014. doi:10.1038/mto.2016.14

110. Maude SL, Shpall EJ, Grupp SA. Chimeric antigen receptor T-cell therapy for ALL. Hematology Am Soc Hematol Educ Program (2014) 2014(1):559-64. doi:10.1182/asheducation-2014.1.559

111. Davila ML, Brentjens R. Chimeric antigen receptor therapy for chronic lymphocytic leukemia: what are the challenges? Hematol Oncol Clin North Am (2013) 27(2):341-53. doi:10.1016/j.hoc.2012.12.004

112. Kochenderfer JN, Dudley ME, Feldman SA, Wilson WH, Spaner DE, Maric I, et al. B-cell depletion and remissions of malignancy along with cytokine-associated toxicity in a clinical trial of anti-CD19 chimeric-antigen-receptor-transduced T cells. Blood (2012) 119(12):2709-20. doi:10.1182/ blood-2011-10-384388 
113. Jackson HJ, Rafiq S, Brentjens RJ. Driving CAR T-cells forward. Nat Rev Clin Oncol (2016) 13(6):370-83. doi:10.1038/nrclinonc.2016.36

114. Urba WJ, Longo DL. Redirecting T cells. N Engl J Med (2011) 365(8):754-7. doi:10.1056/NEJMe1106965

115. Jena B, Moyes JS, Huls H, Cooper LJ. Driving CAR-based T-cell therapy to success. Curr Hematol Malig Rep (2014) 9(1):50-6. doi:10.1007/s11899013-0197-7

116. Curran KJ, Pegram HJ, Brentjens RJ. Chimeric antigen receptors for T cell immunotherapy: current understanding and future directions. J Gene Med (2012) 14(6):405-15. doi:10.1002/jgm.2604

117. Oh I, Oh Y, Ohmine K. Adoptive immunotherapy utilizing anti-CD19 chimeric antigen receptor T-cells for B-cell malignancies. Rinsho Ketsueki (2016) 57(11):2365-72. doi:10.11406/rinketsu.57.2365

118. Kochenderfer JN, Rosenberg SA. Treating B-cell cancer with $\mathrm{T}$ cells expressing anti-CD19 chimeric antigen receptors. Nat Rev Clin Oncol (2013) 10(5):267-76. doi:10.1038/nrclinonc.2013.46

119. Maher J, Wilkie S, Davies DM, Arif S, Picco G, Julien S, et al. Targeting of tumor-associated glycoforms of MUC1 with CAR T cells. Immunity (2016) 45(5):945-6. doi:10.1016/j.immuni.2016.10.014

120. Song DG, Powell DJ. Pro-survival signaling via CD27 costimulation drives effective CAR T-cell therapy. Oncoimmunology (2012) 1(4):547-9. doi:10.4161/onci. 19458

121. Hombach AA, Abken H. Young T cells age during a redirected anti-tumor attack: chimeric antigen receptor-provided dual costimulation is half the battle. Front Immunol (2013) 4:135. doi:10.3389/fimmu.2013.00135

122. Santos EB, Yeh R, Lee J, Nikhamin Y, Punzalan B, Punzalan B, et al. Sensitive in vivo imaging of $\mathrm{T}$ cells using a membrane-bound Gaussia princeps luciferase. Nat Med (2009) 15(3):338-44. doi:10.1038/nm.1930

123. Hollyman D, Stefanski J, Przybylowski M, Bartido S, Borquez-Ojeda O, Taylor C, et al. Manufacturing validation of biologically functional T cells targeted to CD19 antigen for autologous adoptive cell therapy. J Immunother (2009) 32(2):169-80. doi:10.1097/CJI.0b013e318194a6e8

124. Maude SL, Barrett D, Teachey DT, Grupp SA. Managing cytokine release syndrome associated with novel T cell-engaging therapies. Cancer J (2014) 20(2):119-22. doi:10.1097/PPO.0000000000000035

125. Nishio N, Diaconu I, Liu H, Cerullo V, Caruana I, Hoyos V, et al. Armed oncolytic virus enhances immune functions of chimeric antigen receptor-modified T cells in solid tumors. Cancer Res (2014) 74(18): 5195-205. doi:10.1158/0008-5472.CAN-14-0697

126. Savoldo B, Ramos CA, Liu E, Mims MP, Keating MJ, Carrum G, et al. CD28 costimulation improves expansion and persistence of chimeric antigen receptor-modified T cells in lymphoma patients. J Clin Invest (2011) 121(5):1822-6. doi:10.1172/JCI46110

127. Tammana S, Huang X, Wong M, Milone MC, Ma L, Levine BL, et al. 4-1BB and CD28 signaling plays a synergistic role in redirecting umbilical cord blood T cells against B-cell malignancies. Hum Gene Ther (2010) 21(1):75-86. doi:10.1089/hum.2009.122

128. Mamonkin M, Mukherjee M, Srinivasan M, Sharma S, Gomes-Silva D, Mo F, et al. Reversible transgene expression reduces fratricide and permits 4-1BB costimulation of CAR T cells directed to T-cell malignancies. Cancer Immunol Res (2017) 6(1):47-58. doi:10.1158/2326-6066.CIR-17-0126

129. Barrett DM, Singh N, Liu X, Jiang S, June CH, Grupp SA, et al. Relation of clinical culture method to T-cell memory status and efficacy in xenograft models of adoptive immunotherapy. Cytotherapy (2014) 16(5):619-30. doi:10.1016/j.jcyt.2013.10.013

130. Guedan S, Chen X, Madar A, Carpenito C, McGettigan SE, Frigault MJ, et al. ICOS-based chimeric antigen receptors program bipolar TH17/TH1 cells. Blood (2014) 124(7):1070-80. doi:10.1182/blood-2013-10-535245

131. Hombach AA, Rappl G, Abken H. Arming cytokine-induced killer cells with chimeric antigen receptors: $\mathrm{CD} 28$ outperforms combined CD28-OX40 "super-stimulation". Mol Ther (2013) 21(12):2268-77. doi:10.1038/ mt.2013.192

132. Hombach AA, Holzinger A, Abken H. The weal and woe of costimulation in the adoptive therapy of cancer with chimeric antigen receptor (CAR)redirected T cells. Curr Mol Med (2013) 13(7):1079-88. doi:10.2174/15665 24011313070003

133. Novosiadly R, Kalos M. High-content molecular profiling of T-cell therapy in oncology. Mol Ther Oncolytics (2016) 3:16009. doi:10.1038/mto.2016.9
134. Brentjens RJ, Curran KJ. Novel cellular therapies for leukemia: CARmodified $\mathrm{T}$ cells targeted to the CD19 antigen. Hematology Am Soc Hematol Educ Program (2012) 2012:143-51. doi:10.1182/asheducation2012.1.143

135. Gargett T, Brown MP. The inducible caspase- 9 suicide gene system as a "safety switch" to limit on-target, off-tumor toxicities of chimeric antigen receptor T cells. Front Pharmacol (2014) 5:235. doi:10.3389/fphar.2014.00235

136. Imai C, Mihara K, Andreansky M, Nicholson IC, Pui CH, Geiger TL, et al. Chimeric receptors with 4-1BB signaling capacity provoke potent cytotoxicity against acute lymphoblastic leukemia. Leukemia (2004) 18(4):676-84. doi:10.1038/sj.leu.2403302

137. Imai C, Campana D. Genetic modification of $\mathrm{T}$ cells for cancer therapy. J Biol Regul Homeost Agents (2004) 18(1):62-71.

138. Zhu YM, Wu Z, Tan YP, Du YY, Liu Z, Ou RM, et al. Anti-CD19 chimeric antigen receptor T-cell therapy for adult Philadelphia chromosome-positive acute lymphoblastic leukemia: two case reports. Medicine (2016) 95(51):e5676. doi:10.1097/MD.0000000000005676

139. Lim WA, June $\mathrm{CH}$. The principles of engineering immune cells to treat cancer. Cell (2017) 168(4):724-40. doi:10.1016/j.cell.2017.01.016

140. O’Rourke DM, Nasrallah MP, Desai A, Melenhorst JJ, Mansfield K, Morrissette JJD, et al. A single dose of peripherally infused EGFRvIIIdirected CAR T cells mediates antigen loss and induces adaptive resistance in patients with recurrent glioblastoma. Sci Transl Med (2017) 9(399):eaaa0984. doi:10.1126/scitranslmed.aaa0984

141. Tranca S, Oever JT, Ciuce C, Netea M, Slavcovici A, Petrisor C, et al. sTREM-1, sIL-2Ralpha, and IL-6, but not sCD163, might predict sepsis in polytrauma patients: a prospective cohort study. Eur J Trauma Emerg Surg (2017) 43(3):363-70. doi:10.1007/s00068-016-0678-1

142. Neelapu SS, Tummala S, Kebriaei P, Wierda W, Gutierrez C, Locke FL, et al. Chimeric antigen receptor T-cell therapy - assessment and management of toxicities. Nature Rev Clin Oncol (2017) 15(1):47-62. doi:10.1038/ nrclinonc.2017.148

143. Brentjens RJ, Davila ML, Riviere I, Park J, Wang X, Cowell LG, et al. CD19-targeted T cells rapidly induce molecular remissions in adults with chemotherapy-refractory acute lymphoblastic leukemia. Sci Transl Med (2013) 5(177):177ra38. doi:10.1126/scitranslmed.3005930

144. Holohan DR, Lee JC, Bluestone JA. Shifting the evolving CAR T cell platform into higher gear. Cancer Cell (2015) 28(4):401-2. doi:10.1016/j. ccell.2015.09.014

145. Hill JA, Li D, Hay KA, Green ML, Cherian S, Chen X, et al. Infectious complications of CD19-targeted chimeric antigen receptor-modified T cell immunotherapy. Blood (2017) 131(1):121-30. doi:10.1182/blood2017-07-793760

146. Xiao W, Salem D, McCoy CS, Lee D, Shah NN, Stetler-Stevenson M, et al. Early recovery of circulating immature B cells in B-lymphoblastic leukemia patients after CD19 targeted CAR T cell therapy: a pitfall for minimal residual disease detection. Cytometry B Clin Cytom (2017). doi:10.1002/ cyto.b.21591

147. Brudno JN, Kochenderfer JN. Chimeric antigen receptor T-cell therapies for lymphoma. Nat Rev Clin Oncol (2017) 15(1):31-46. doi:10.1038/ nrclinonc.2017.128

148. Nitschke L. CD22 and Siglec-G: B-cell inhibitory receptors with distinct functions. Immunol Rev (2009) 230(1):128-43. doi:10.1111/j.1600-065X. 2009.00801.x

149. Haso W, Lee DW, Shah NN, Stetler-Stevenson M, Yuan CM, Pastan IH, et al. Anti-CD22-chimeric antigen receptors targeting B-cell precursor acute lymphoblastic leukemia. Blood (2013) 121(7):1165-74. doi:10.1182/ blood-2012-06-438002

150. Russell LJ, Capasso M, Vater I, Akasaka T, Bernard OA, Calasanz MJ, et al. Deregulated expression of cytokine receptor gene, CRLF2, is involved in lymphoid transformation in B-cell precursor acute lymphoblastic leukemia. Blood (2009) 114(13):2688-98. doi:10.1182/blood-2009-03-208397

151. Yoda A, Yoda Y, Chiaretti S, Bar-Natan M, Mani K, Rodig SJ, et al. Functional screening identifies CRLF2 in precursor B-cell acute lymphoblastic leukemia. Proc Natl Acad Sci U S A (2010) 107(1):252-7. doi:10.1073/pnas. 0911726107

152. Qin H, Cho M, Haso W, Zhang L, Tasian SK, Oo HZ, et al. Eradication of B-ALL using chimeric antigen receptor-expressing $\mathrm{T}$ cells targeting the 
TSLPR oncoprotein. Blood (2015) 126(5):629-39. doi:10.1182/blood-201411-612903

153. Tomuleasa C, Fuji S, Cucuianu A, Kapp M, Pileczki V, Petrushev B, et al. MicroRNAs as biomarkers for graft-versus-host disease following allogeneic stem cell transplantation. Ann Hematol (2015) 94(7):1081-92. doi:10.1007/s00277-015-2369-0

154. Provasi E, Genovese P, Lombardo A, Magnani Z, Liu PQ, Reik A, et al. Editing $T$ cell specificity towards leukemia by zinc finger nucleases and lentiviral gene transfer. Nat Med (2012) 18(5):807-15. doi:10.1038/nm.2700

155. Cruz CR, Micklethwaite KP, Savoldo B, Ramos CA, Lam S, Ku S, et al. Infusion of donor-derived CD19-redirected virus-specific T cells for B-cell malignancies relapsed after allogeneic stem cell transplant: a phase 1 study. Blood (2013) 122(17):2965-73. doi:10.1182/blood-2013-06-506741

156. Brudno JN, Somerville RP, Shi V, Rose JJ, Halverson DC, Fowler DH, et al. Allogeneic $\mathrm{T}$ cells that express an anti-CD19 chimeric antigen receptor induce remissions of $\mathrm{B}$-cell malignancies that progress after allogeneic hematopoietic stem-cell transplantation without causing graftversus-host disease. J Clin Oncol (2016) 34(10):1112-21. doi:10.1200/ JCO.2015.64.5929

157. Wang LX, Westwood JA, Moeller M, Duong CP, Wei WZ, Malaterre J, et al. Tumor ablation by gene-modified $\mathrm{T}$ cells in the absence of autoimmunity. Cancer Res (2010) 70(23):9591-8. doi:10.1158/0008-5472.CAN-10-2884

158. Kochenderfer JN, Wilson WH, Janik JE, Dudley ME, Stetler-Stevenson M, Feldman SA, et al. Eradication of B-lineage cells and regression of lymphoma in a patient treated with autologous $\mathrm{T}$ cells genetically engineered to recognize CD19. Blood (2010) 116(20):4099-102. doi:10.1182/ blood-2010-04-281931

159. Alcantar-Orozco EM, Gornall H, Baldan V, Hawkins RE, Gilham DE. Potential limitations of the NSG humanized mouse as a model system to optimize engineered human T cell therapy for cancer. Hum Gene Ther Methods (2013) 24(5):310-20. doi:10.1089/hgtb.2013.022

160. HudecekM,Lupo-StanghelliniMT, Kosasih PL,SommermeyerD, JensenMC, Rader C, et al. Receptor affinity and extracellular domain modifications affect tumor recognition by ROR1-specific chimeric antigen receptor T cells. Clin Cancer Res (2013) 19(12):3153-64. doi:10.1158/1078-0432. CCR-13-0330

161. Casucci M, Nicolis di Robilant B, Falcone L, Camisa B, Norelli M, Genovese P, et al. CD44v6-targeted $\mathrm{T}$ cells mediate potent antitumor effects against acute myeloid leukemia and multiple myeloma. Blood (2013) 122(20):3461-72. doi:10.1182/blood-2013-04-493361

162. Chu Y, Hochberg J, Yahr A, Ayello J, van de Ven C, Barth M, et al. Targeting CD20+ aggressive B-cell non-hodgkin lymphoma by Anti-CD20 CAR mRNA-modified expanded natural killer cells in vitro and in NSG Mice. Cancer Immunol Res (2015) 3(4):333-44. doi:10.1158/2326-6066. CIR-14-0114

163. Gregoire C, Chasson L, Luci C, Tomasello E, Geissmann F, Vivier E, et al. The trafficking of natural killer cells. Immunol Rev (2007) 220:169-82. doi:10.1111/j.1600-065X.2007.00563.x

164. De Maria A, Bozzano F, Cantoni C, Moretta L. Revisiting human natural killer cell subset function revealed cytolytic CD56(dim)CD16+ NK cells as rapid producers of abundant IFN-gamma on activation. Proc Natl Acad Sci US A (2011) 108(2):728-32. doi:10.1073/pnas.1012356108

165. Yvon E, Del Vecchio M, Savoldo B, Hoyos V, Dutour A, Anichini A, et al. Immunotherapy of metastatic melanoma using genetically engineered GD2-specific T cells. Clin Cancer Res (2009) 15(18):5852-60. doi:10.1158/1078-0432.CCR-08-3163

166. Sommermeyer D, Hudecek M, Kosasih PL, Gogishvili T, Maloney DG, Turtle CJ, et al. Chimeric antigen receptor-modified $\mathrm{T}$ cells derived from defined CD8+ and CD4+ subsets confer superior antitumor reactivity in vivo. Leukemia (2016) 30(2):492-500. doi:10.1038/leu.2015.247

167. Gattinoni L, Finkelstein SE, Klebanoff CA, Antony PA, Palmer DC, Spiess PJ, et al. Removal of homeostatic cytokine sinks by lymphodepletion enhances the efficacy of adoptively transferred tumor-specific CD8+ T cells. J Exp Med (2005) 202(7):907-12. doi:10.1084/jem.20050732

168. Klebanoff CA, Gattinoni L, Torabi-Parizi P, Kerstann K, Cardones AR, Finkelstein SE, et al. Central memory self/tumor-reactive CD8+ T cells confer superior antitumor immunity compared with effector memory T cells. Proc Natl Acad Sci U S A (2005) 102(27):9571-6. doi:10.1073/ pnas.0503726102

169. Rossig C, Bollard CM, Nuchtern JG, Rooney CM, Brenner MK. EpsteinBarr virus-specific human $\mathrm{T}$ lymphocytes expressing antitumor chimeric T-cell receptors: potential for improved immunotherapy. Blood (2002) 99(6):2009-16. doi:10.1182/blood.V99.6.2009

170. Cooper LJ, Al-Kadhimi Z, Serrano LM, Pfeiffer T, Olivares S, Castro A, et al. Enhanced antilymphoma efficacy of CD19-redirected influenza MP1specific CTLs by cotransfer of T cells modified to present influenza MP1. Blood (2005) 105(4):1622-31. doi:10.1182/blood-2004-03-1208

171. Savoldo B, Rooney CM, Di Stasi A, Abken H, Hombach A, Foster AE, et al. Epstein Barr virus specific cytotoxic T lymphocytes expressing the anti-CD30zeta artificial chimeric T-cell receptor for immunotherapy of Hodgkin disease. Blood (2007) 110(7):2620-30. doi:10.1182/blood2006-11-059139

172. Louis CU, Savoldo B, Dotti G, Pule M, Yvon E, Myers GD, et al. Antitumor activity and long-term fate of chimeric antigen receptor-positive $\mathrm{T}$ cells in patients with neuroblastoma. Blood (2011) 118(23):6050-6. doi:10.1182/ blood-2011-05-354449

173. Pule MA, Savoldo B, Myers GD, Rossig C, Russell HV, Dotti G, et al. Virus-specific $\mathrm{T}$ cells engineered to coexpress tumor-specific receptors: persistence and antitumor activity in individuals with neuroblastoma. Nat Med (2008) 14(11):1264-70. doi:10.1038/nm.1882

174. Chmielewski M, Kopecky C, Hombach AA, Abken H. IL-12 release by engineered $\mathrm{T}$ cells expressing chimeric antigen receptors can effectively Muster an antigen-independent macrophage response on tumor cells that have shut down tumor antigen expression. Cancer Res (2011) 71(17):5697-706. doi:10.1158/0008-5472.CAN-11-0103

175. Yeku OO, Brentjens RJ. Armored CAR T-cells: utilizing cytokines and pro-inflammatory ligands to enhance CAR T-cell anti-tumour efficacy. Biochem Soc Trans (2016) 44(2):412-8. doi:10.1042/BST20150291

176. Roybal KT, Williams JZ, Morsut L, Rupp LJ, Kolinko I, Choe JH, et al. Engineering T cells with customized therapeutic response programs using synthetic notch receptors. Cell (2016) 167(2):419-32e16. doi:10.1016/j. cell.2016.09.011

Conflict of Interest Statement: The authors declare that the research was conducted in the absence of any commercial or financial relationships that could be construed as a potential conflict of interest.

Copyright () 2018 Tomuleasa, Fuji, Berce, Onaciu, Chira, Petrushev, Micu, Moisoiu, Osan, Constantinescu, Pasca, Jurj, Pop, Berindan-Neagoe, Dima and Kitano. This is an open-access article distributed under the terms of the Creative Commons Attribution License (CC BY). The use, distribution or reproduction in other forums is permitted, provided the original author(s) and the copyright owner are credited and that the original publication in this journal is cited, in accordance with accepted academic practice. No use, distribution or reproduction is permitted which does not comply with these terms. 